\title{
Potential impacts from tephra fall to electric power systems: a review and mitigation strategies
}

\author{
J. B. Wardman • T. M. Wilson • P. S. Bodger • \\ J. W. Cole • C. Stewart
}

Received: 9 May 2012 / Accepted: 20 September 2012

(C) Springer-Verlag Berlin Heidelberg 2012

\begin{abstract}
Modern society is highly dependent on a reliable electricity supply. During explosive volcanic eruptions, tephra contamination of power networks (systems) can compromise the reliability of supply. Outages can have significant cascading impacts for other critical infrastructure sectors and for society as a whole. This paper summarises known impacts to power systems following tephra falls since 1980. The main impacts are (1) supply outages from insulator flashover caused by tephra contamination, (2) disruption of generation facilities, (3) controlled outages during tephra cleaning, (4) abrasion and corrosion of exposed equipment and (5) line (conductor) breakage due to tephra loading. Of these impacts, insulator flashover is the most common disruption. The review highlights multiple instances of electric power systems exhibiting tolerance to tephra falls, suggesting that failure thresholds exist and should be
\end{abstract}

Editorial responsibility: S. Self

Electronic supplementary material The online version of this article (doi:10.1007/s00445-012-0664-3) contains supplementary material, which is available to authorized users.

J. B. Wardman $(\bowtie) \cdot$ T. M. Wilson · J. W. Cole $\cdot$ C. Stewart Department of Geological Sciences, University of Canterbury, Private Bag 4800,

Christchurch 8140, New Zealand

e-mail: jbwardman@gmail.com

T. M. Wilson

e-mail: thomas.wilson@canterbury.ac.nz

J. W. Cole

e-mail: jim.cole@canterbury.ac.nz

C. Stewart

e-mail: carol.stewart@canterbury.ac.nz

\section{P. S. Bodger}

Department of Electrical and Computer Engineering,

University of Canterbury,

Private Bag 4800,

Christchurch 8140, New Zealand

e-mail: pat.bodger@canterbury.ac.nz identified to avoid future unplanned interruptions. To address this need, we have produced a fragility function that quantifies the likelihood of insulator flashover at different thicknesses of tephra. Finally, based on our review of case studies, potential mitigation strategies are summarised. Specifically, avoiding tephra-induced insulator flashover by cleaning key facilities such as generation sites and transmission and distribution substations is of critical importance in maintaining the integrity of an electric power system.

Keywords Volcanic ash · Eruption · Electricity · Generation $\cdot$ Transmission $\cdot$ Distribution $\cdot$ Substation

\section{Introduction}

Electricity is the 'life blood' of modern society (Lawrence 1988). Increasing demand for electricity has been driven by population growth and increasing use of electrically powered technologies. Electricity supply is arguably the most essential contemporary infrastructure, especially considering the dependencies of other infrastructure groups on electric power to maintain functionality (Fig. 1). Given that $9 \%$ of the world's population is estimated to live within $100 \mathrm{~km}$ of a historically active volcano (Horwell and Baxter 2006), and many of these areas are experiencing significant population and economic growth, their exposure and vulnerability to the impacts of volcanic hazards is increasing (Johnston et al. 2000). Effective disaster risk reduction and infrastructure management thus makes it imperative that system operators understand the potential impacts from natural disasters and take the necessary precautions to avoid unintended interruptions.

Although pyroclastic flows and surges, sector collapses, lahars and ballistic blocks are the most destructive and dangerous of explosive eruption products (Baxter 1990; Hansell et al. 2006; GFDRR 2011), tephra fall is the most 


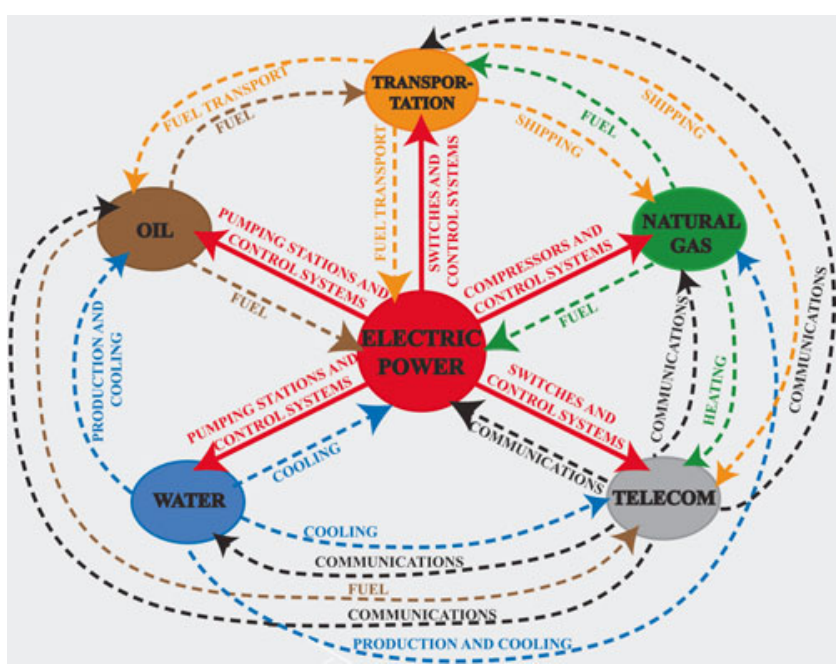

Fig. 1 Schematic diagram illustrating some of the interdependencies between critical infrastructure systems (adapted from Rinaldi et al. 2001)

widespread volcanic phenomenon. Tephra is the product of explosive volcanic eruptions and is composed of pulverised fragments of rock, minerals and glass $\left(\mathrm{SiO}_{2}\right)$. Fine-grained tephra (defined here as $<2 \mathrm{~mm}$ particle diameter), also known as volcanic ash (Rose and Durant 2009), can be dispersed large distances by winds. Even in small eruptions, thousands of square kilometres may be impacted by tephra falls (Johnston et al. 2000). Extensive, above-ground, corridor systems of electrical apparatus used in power generation, transformation, transmission, and distribution often stretch hundreds to thousands of kilometres, making them highly exposed to such tephra falls. This high level of exposure emphasises the need to understand the vulnerabilities of power systems in both proximal and distal locations.

Tephra can cause disruption to electricity generation and supply in the following ways (adapted from Wilson et al. 2009):

1. High-voltage (HV) insulators (porcelain, glass or composite) are electrical hardware designed to mechanically support and electrically isolate energized lines or apparatus from earthed (bonded with the ground) structures such as steel towers or wooden poles. During humid conditions such as light rain, fog, or mist, wet deposits of tephra on insulators can initiate a leakage current (small amount of current flow across the insulator surface) that, if sufficient current is achieved, can cause 'flashover' (the unintended electrical discharge around or over the surface of an insulator). If the resulting short-circuit current is high enough to trip the circuit breaker, then disruption of service will occur. The presence of leakage current is due to the electrical conductivity of the wet tephra, which is influenced by (1) moisture content, (2) soluble salt content, (3) compaction and, to a lesser extent, (4) grain size (refer to Wardman et al. 2012b for further information). Tephra- induced flashover on or across power transformer insulation (bushings) can burn, etch or crack the insulation irreparably and potentially damage the internal components (e.g. windings) of the transformer.

2. Controlled outages of vulnerable nodes (e.g. generation facilities and/or substations) or circuits until tephra fall has subsided or for offline (de-energised) cleaning of equipment.

3. The hardness and angularity of tephra make it highly abrasive. Tephra can accelerate normal wear by eroding and scouring metallic apparatus, particularly moving parts such as water and wind turbines at generation sites and cooling fans on power transformers.

4. The high bulk density of some tephra deposits can cause line breakage due to tephra loading. This is most hazardous when the tephra and/or the lines are wet and usually following at least $10 \mathrm{~mm}$ of tephra fall. Finegrained tephra adheres to lines and structures (e.g. wooden poles and steel towers) most readily. Tephra may also load overhanging vegetation, causing it to fall onto lines which can bridge (make contact between) phases (lines) or cause line breakage and/or damage to structures. Snow and ice accumulation on lines and overhanging vegetation further exacerbates the risk.

5. Tephra ingress can block air intakes causing a reduction of air intake quality and quantity for turbines and cooling and heating, ventilation and air conditioning (HVAC) systems at generation sites and substations. This may lead to a reduction in efficiency, precautionary shut-down (to avoid damage), damage or even failure. Tephra could potentially abrade, clog and corrode thermal turbines and control systems following ingestion, although these impacts have not been recorded.

In this paper, we provide an overview of the recorded impacts to power systems from volcanic eruptions since 1980 (Table 1). We have compiled data from existing literature, personal communications with system operators during meetings and semi-structured interviews, and field observations from around the world to summarise electricity system performance following tephra falls and successful mitigation strategies. Given the lack of existing data, we have developed a fragility function that provides an estimate for the likelihood of insulator flashover at different thicknesses of wet or dry tephra. This study ultimately aims to inform the volcanological, hazard mitigation and electrical engineering communities of the potential adverse impacts arising from tephra contamination and provide best-practise and impact-specific mitigation advice.

\section{Research context}

Over the past 15 years, our international research group led by the University of Canterbury and GNS Science, New 
Table 1 General information on the nine volcanoes used as case studies within this paper (data compiled from Siebert and Simkin 2002)

\begin{tabular}{llllll}
\hline Volcano & Country & $\begin{array}{l}\text { Year(s) of case } \\
\text { study eruption }\end{array}$ & Volcano type & VEI & Tephra composition \\
\hline Mt St Helens & USA. & 1980 & Stratovolcano & 5 & Dacite \\
Redoubt & USA. & $1989 / 1990$ & Stratovolcano & 3 & Andesite \\
Rabaul & Papua New Guinea & 1994 & Caldera & 4 & Andesite \\
Soufrière Hills & Montserrat (UK) & $1995-2011$ & Stratovolcano & 3 & Andesite \\
Ruapehu & New Zealand & $1995 / 1996$ & Stratovolcano & 3 & Basaltic-Andesite \\
Chaitén & Chile & 2008 & Caldera & 4 & Rhyolite \\
Pacaya & Guatemala & 2010 & Scoria Cone & 3 & Basalt \\
Tungurahua & Ecuador & $1999-2010$ & Stratovolcano & 3 & Andesite \\
Shinmoe-dake & Japan & 2011 & Shield & 3 & Andesite \\
\hline
\end{tabular}

Zealand has aimed to undertake a sustained and systematic approach to volcanic impact assessment in critical infrastructure (e.g. electricity; see Wilson et al. 2012 for more information). Meetings and interviews were carried out with infrastructure managers, and operations and maintenance staff at affected facilities. The interviews followed an extensive group of prompt questions that were used to steer the conversation, and touched upon the main topics of interest for research, including the general impacts of tephra fall on the sector, actions taken in response to tephra fall, tephra clean-up operations, emergency management plans and interdependency issues. Interviews were semi-structured in nature to allow for more open exploration and discussion around the various topics that were brought up in conversation (refer to Electronic supplementary material).

Critical components of a power system

The basic function of a power system is to supply customers, both major and minor, with electrical energy as economically as possible and with an acceptable degree of reliability and quality (Billinton and Allan 1988). There are four main components of the modern electric power industry: (1) generation, (2) transmission (e.g. $>110 \mathrm{kV}$ by USA standards), (3) sub-transmission (e.g. 33 to $110 \mathrm{kV}$ ) and (4) distribution (e.g. $<33 \mathrm{kV}$ ), as illustrated in Fig. 2. Generation sites transform the stored energy present in fossil (oil, coal, natural gas, etc.), nuclear and renewable (geothermal fluids, wind, solar or water) fuels into electric energy. A typical alternating current generator produces a voltage of around 11 to $25 \mathrm{kV}$. This voltage is increased by a step-up transformer (increase in voltage, decrease in current) to facilitate the transmission of power over large distances. The transmitted power then passes through a 'switchyard' which is a facility dedicated to feeding power to different sections of the system (voltage is neither increased nor decreased at switchyards). Once the power reaches a substation located on the edge of a town or city, the voltage is reduced for integration into a sub-transmission system where power is fed to many distribution substations (e.g. within cities). At the distribution substation, the voltage is reduced again and the power fed into a localised system of overhead or underground 'distribution' lines. Large industrial plants and factories are usually supplied directly by a sub-transmission line or dedicated distribution line. Before residential consumption, however, the line voltage is reduced to $\sim 400 / 220 \mathrm{~V}$ (depending on the system used) by distribution transformers that are commonly mounted on distribution poles or in ground placed kiosks.

For this review, we have simplified the components of modern electricity systems into (a) generation facilities, (b) transmission and distribution components (insulators, lines, towers, poles, low-voltage transformers (e.g. $<33 \mathrm{kV}$ ), etc.), and (c) substations and switchyards.

\section{Direct impacts to power systems}

\section{Case studies}

The following section summarises impacts from tephra falls to the three aforementioned components of a power system using impact assessment case studies carried out on nine eruptions (refer to Table 1 for more detail): Mt. St. Helens, USA (1980); Redoubt, USA (1989/1990); Rabaul, Papua New Guinea (1994); Ruapehu, New Zealand (1995/1996); Tungurahua, Ecuador (1999-2010); Chaitén, Chile (2008); Soufrière Hills, Montserrat (1995-2011); Pacaya, Guatemala (2010) and Shinmoe-dake, Japan (2011). The review has been organised by impact type within each sector of the modern power system.

Ideally, we would have provided information on the physical (e.g. grain size distributions, particle morphology, etc.), chemical (e.g. bulk rock chemistry, soluble salt content, etc.) and electrical properties (e.g. conductivity) of the tephras found at specific impact sites for each of the eruptions. This would allow analysis of tephra properties most likely to lead to power system impacts. However, 


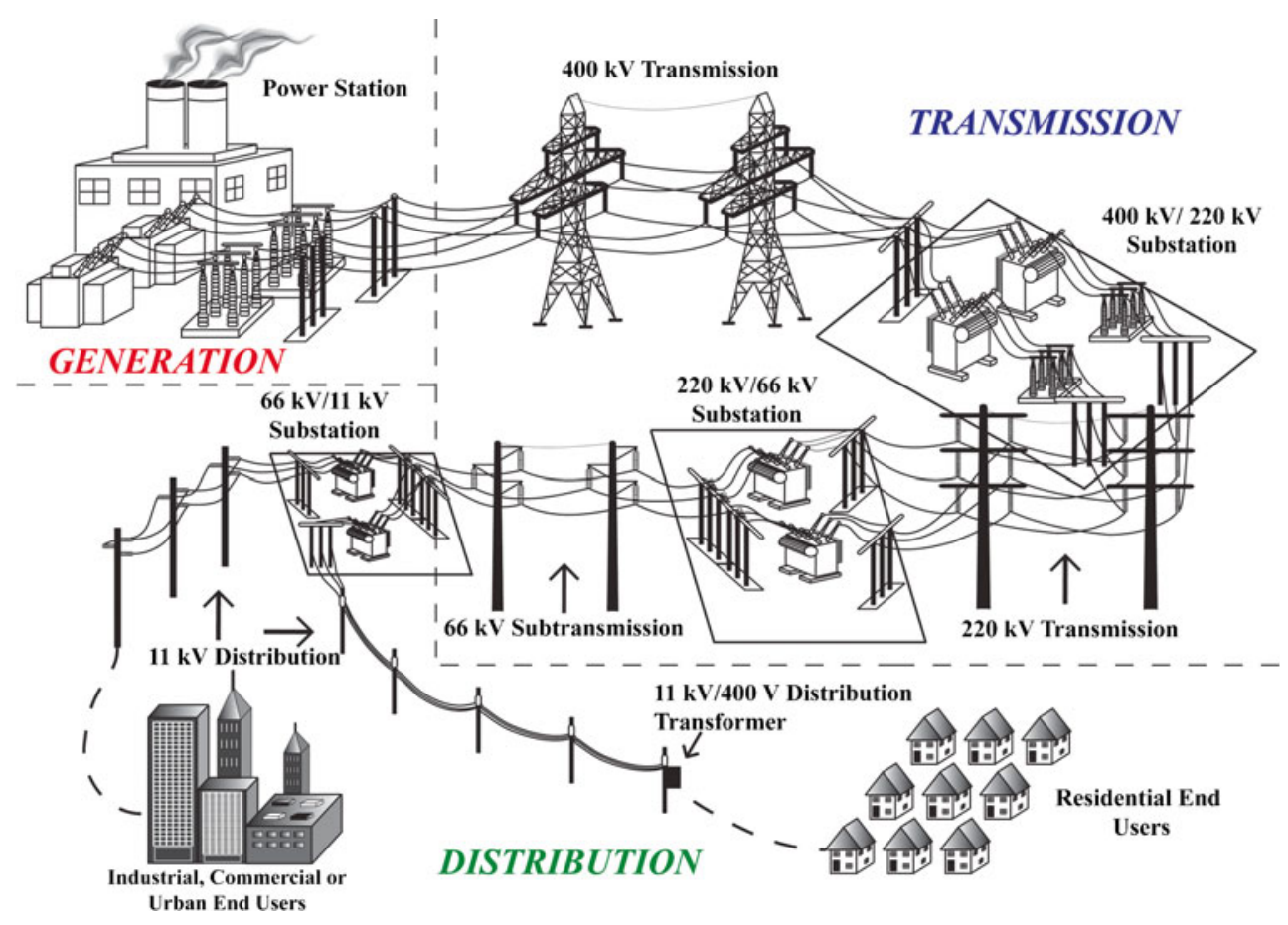

Fig. 2 An example of a modern electric power system. Electric energy is generated at a power station (e.g. $13 \mathrm{kV}$ ). From here, the voltage is increased (current decreased) and the energy transmitted at $400 \mathrm{kV}$ via extra-high voltage (EHV) transmission lines to a $400 / 220 \mathrm{kV}$ EHV substation. The energy is then transmitted to a HV substation where the voltage is reduced to $66 \mathrm{kV}$. Sub-transmission lines connect the HV substations to many distribution substations located within cities,

assembling this information is extremely challenging because (1) information on tephra properties at the specific locations where power systems have been impacted is rarely reported by power system personnel. Consequentially, we rely on tephra studies by other volcanological authors who have not collected tephra samples at the sites of affected power systems or analysed tephra for electrical properties; (2) some explosive eruptions examined within this study have durations of months to years, making it difficult to sample any one tephra deposit (e.g. Soufrière Hills and Tungurahua); (3) tephra samples rapidly leach and immediate weathering following deposition makes it hard, if not impossible, to retrospectively sample representative tephra from specific impact sites; and (4) the exact dates and specific locations of impact(s) on long, expansive power system assets are, in most cases, unknown. Previous work done by Wardman et al. (2012b) has shown that variables such as moisture content, soluble salt content, grain size, bulk density and composition are key controls on the electrical conductivity of volcanic ash. To avoid broad assumptions about the electrical properties of the tephras in the following case studies, and in the absence of site-specific data, tephra thickness has been estimated from isopach maps and used here where available. where the voltage is reduced to $11 \mathrm{kV}$ and the energy finally distributed either directly to industrial plants or factories or to local residential and commercial zones. Distribution transformers (ground or pole mounted) reduce the voltage from $11 \mathrm{kV}$ to $\sim 400 / 220 \mathrm{~V}$ (depending on the system used) for use in homes, shopping centres and other local loads (adapted from Karady 2007)

\section{Generation}

\section{Accelerated wear at hydroelectric power sites}

The 1995/1996 eruption of Mt. Ruapehu deposited roughly 7.6 million cubic metres of tephra on the Rangipo hydroelectric power (HEP) catchment (Meredith 2007). This caused high levels of suspended tephra in the Tongariro River. In the 7 months following the initial eruption, an estimated $5 \mathrm{t}$ of tephra had passed through the system and approximately 15 years worth of normal wear had been experienced by the turbines (Meredith 2007). Pitting and accelerated erosion were experienced by all generation equipment that came in contact with the tephra-laden water.

Approximately 1 year after the eruption, the $120 \mathrm{MW}$ plant halted operations to carry out repairs to its two turbines and all auxiliary components, causing an estimated loss of generation in excess of NZ\$12 million (Johnston et al. 2000). To combat the effects of erosion and pitting, a protective coating was applied to turbine components-runner blades, labyrinth seals, wear rings, band seal, cheek plates and wicket gates. A hard coating (tungsten carbide powder) was applied to those components considered most critical to the system (e.g. crown, blades and band seal) while a soft 
coating (polyurethane) was applied to most of the other parts of the runner. As of 2007, the repaired turbines had been operating efficiently with minimal wear (Meredith 2007).

The 156 MW Agoyan HEP faciility, located $5 \mathrm{~km}$ east of the city of Baños in Ecuador, is the second most important generation facility in the country (Hall et al. 1999). Since the onset of intermittent volcanic activity from Tungurahua volcano in 1999, very little tephra has fallen at the dam site, and on the few occasions when tephra has fallen at Agoyan, the dam has operated normally. However, during October 1999 and August 2006, large volumes of tephra fall (>100 mm) fell on Baños and the local municipality deemed the community risk too great for people to remain in the town. The heavy amount of tephra fall resulted in the evacuation of Baños residents and closure of local utilities, including the dam.

However, while the dam turbines, generators and control house are located in a zone of low-frequency tephra fallout, the Pastaza catchment of the dam is often exposed to significant tephra fall, leading to significant suspended solids in the water and occasionally lahar hazards, which are more threatening to the Agoyan HEP than direct tephra fall (Sword-Daniels et al. 2011). Intake mechanisms such as wicket gates, turbine covers and blades are particularly at risk of abrasion from the tephra-laden water. Severe pitting and scouring of the metallic components (Fig. 3) have accelerated their degradation, and four turbines have been replaced in the last 21 years.

To reduce the impacts from the intake of highly turbid water, Agoyan has a specially designed floodgate system in place so that the intake flow can be diverted away from generation components and directly flushed out into the river (Fig. 3, inset). When there is heavy rain, causing an increased risk of tephra-laden floodwaters and lahars, the dam operators monitor water levels and turbidity, and activate the protective bypass system as required.

\section{Tephra-induced insulator flashover}

At Futaleufu (HEP) dam, Argentina (86 km from Chaitén volcano), major faults (flashovers) occurred on circuit breaker columns at the facility's control station following $50-100 \mathrm{~mm}$ of very fine-grained $(<0.1 \mathrm{~mm}$ diameter) rhyolitic tephra fall from the 2008 Chaitén eruption (Wilson et al. 2011). Flashovers also occurred across HV insulators on the $240 \mathrm{kV}$ transmissions lines adjacent to the station, following light rain (estimated at $2 \mathrm{~mm} /$ hour) on 6 May 2008. The intense heat and severity of the arc during flashovers caused several of the insulators to explode and their metal pins to fuse, requiring total replacement of the insulators.

To avoid build-up from further tephra falls and wind remobilisation of tephra deposits, insulators were cleaned at the powerhouse and on the incoming transmission lines every 10 days for several months. The fine-grained tephra did not wash off easily having formed a cement-like paste following wetting and drying, even when high-pressure water blasters were used. Generation at the HEP dam was unaffected by the tephra fall or tephra-laden water and remained in-service for the duration the eruption. However, when adjacent transmission lines were disrupted due to tephra-induced insulator flashover, generation ceased (Wilson et al. 2011).

\section{Tephra ingress}

On the Caribbean island of Montserrat, intermittent tephra falls from Soufrière Hills volcano at the Montserrat Utilities Limited generation yard (located $9 \mathrm{~km}$ northwest of the volcano) have to be regularly washed away with water to prevent tephra ingress (e.g. via wind mobilization) into the diesel generators. Tephra fall events occur more often in active phases of dome growth, of which there have been five since the onset of the eruption in 1995. Tephra is carried to
Fig. 3 A severely abraded turbine that was removed from service at the Agoyan hydroelectric power plant, which is sited $5 \mathrm{~km}$ east of Tungurahua volcano. Tephraladen water filtering through the turbines has necessitated the replacement of four turbines in 21 years. Bottom inset: The Agoyan Dam and its (orange) floodgates are designed to let highly turbid water bypass the turbines so as to avoid accelerated wear of generation components

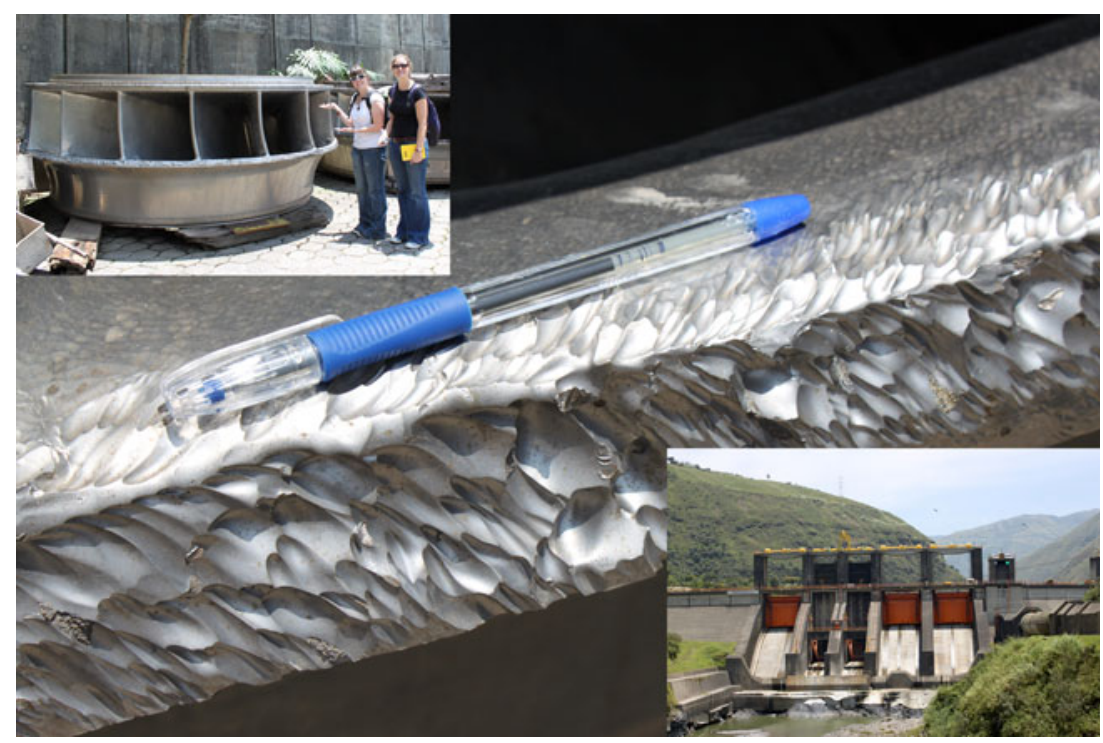


the west by the prevailing wind, but occasionally northwest to the inhabited areas, where it can affect the generation yard. Air intake filters are changed more frequently using high-pressure water blasters every day during and after tephra fall events (Sword-Daniels 2010).

\section{Controlled shut-down}

Following tephra fall during the 2011 eruption of Shinmoedake, the Kyūshū Electric Power Company (KEPC) initiated a controlled shut-down of the Nojiri and the Mizonokuchi HEPs to avoid tephra ingress into their turbines. KEPC initiated a mudflow (lahar) monitoring programme that culminated in a precautionary shut-down of these plants following heavy rainfall on 10 February. The shut-down effectively avoided tephra impacts, and the shut-down and restart procedures were carried out without problems.

Transmission and distribution system components

\section{Tephra-induced insulator flashover}

The 1980 Mt. St. Helens eruptions deposited tephra over much of northwestern USA, in particular Washington State. The Bonneville Power Administration (BPA) transmits bulk electrical energy across the Pacific Northwest and experienced several tephra-related outages during the eruption. BPA reported that by 28 May 1980 (10 days after the initial eruption), approximately 25 momentary and 25 sustained outages had been recorded (up to $7 \mathrm{~h}$ and $40 \mathrm{~min}$ ) mainly on
$115 \mathrm{kV}$ and lower voltage systems serving customer utilities (Blong 1984). A summary of the flashover incidents reported by Nellis and Hendrix (1980) is provided in Table 2.

Redoubt volcano, located on the west side of Cook Inlet in Alaska, erupted explosively on 20 separate occasions between December 1989 and April 1990 (Miller and Chouet 1994). In December 1989, power outages resulting from insulator flashover occurred in the Twin City area, Kenai, after receiving $\sim 6 \mathrm{~mm}$ of tephra in conjunction with rain (Johnston 1997a).

Falls of tephra and mud from the Ruapehu eruption on 25 September 1995 caused flashovers on Transpower's HV $(220 \mathrm{kV})$ lines located near the base of the volcano ( $\sim 15 \mathrm{~km}$ from the vent). Approximately $3 \mathrm{~mm}$ of finegrained (particles typically $<250 \mu \mathrm{m}$ diameter), wet tephra coated the towers, conductors $(220 \mathrm{kV})$ and glass insulators east (downwind) of the volcano (Transpower 1995; Cronin et al. 2003). Strain insulators, which are oriented horizontally to anchor the ends of a line segment, flashed over. This caused voltage fluctuations and problems for electrical equipment throughout the North Island. For example, fluctuations in supply tripped the emergency power at Wellington Hospital causing non-essential supplies to be shed (Johnston et al. 2000). In addition, Transpower's automated reclose system, which recloses (reconnects) a circuit after a fault has occurred, had to be operated manually during the 1995-1996 eruptions because of the repeated tephra-induced flashovers with every auto-reclose attempt (Wilson et al. 2009).

Table 2 Flashovers on the Bonneville Power Administration system following the 1980 Mt. St. Helens eruption

\begin{tabular}{|c|c|c|c|c|c|}
\hline $\begin{array}{l}\text { Date of } \\
\text { tephra } \\
\text { fallout }\end{array}$ & $\begin{array}{l}\text { Date(s) } \\
\text { of impact }\end{array}$ & $\begin{array}{l}\text { Tephra } \\
\text { received } \\
(\mathrm{mm})\end{array}$ & $\begin{array}{l}\operatorname{Line}(s) \\
(\mathrm{kV})\end{array}$ & Explanation & Comments \\
\hline 18 May & 18-25 May & $\leq 12$ & $\leq 500$ & $\begin{array}{l}\text { Momentary outage on BPA's Lower } \\
\text { Monumental-Hanford } 500 \mathrm{kV} \text { line } \\
\text { and numerous flashover-related } \\
\text { outages reported by customer utilities. }\end{array}$ & $\begin{array}{l}\text { Tephra from the } 18 \text { May eruption fell } \\
\text { dry and did not cause immediate } \\
\text { issues. Flashovers occurred when } \\
7-12 \mathrm{~mm} \text { rain was received over } \\
\text { the } 1 \text {-week period following the } \\
\text { initial } 18 \text { May fallout. }\end{array}$ \\
\hline 18 May & 18-25 May & $\leq 12$ & $<115$ & $\begin{array}{l}\text { Numerous outages mainly on } 115 \mathrm{kV} \\
\text { or lower voltage systems serving } \\
\text { customer utilities. }\end{array}$ & $\begin{array}{l}\text { Some incidents initiated by tephra } \\
\text { loading on trees which caused } \\
\text { branches to make contact with } \\
\text { energised lines. }\end{array}$ \\
\hline 25 May & 26 May & $\leq 12$ & 500 & $\begin{array}{l}\text { Paul Allston } 500 \mathrm{kV} \text { line trip-out due } \\
\text { to suspected tephra contamination. }\end{array}$ & $\begin{array}{l}\text { Evidence of flashover across a jumper } \\
\text { string found during a post } 25 \\
\text { May survey. }\end{array}$ \\
\hline 25 May & 27 May & $6-9$ & 69 & $\begin{array}{l}\text { Phase-to-phase (line to line) flashover } \\
\text { between two } 69 \mathrm{kV} \text { porcelain } \\
\text { post-type insulators. }\end{array}$ & $\begin{array}{l}\text { One insulator exploded from the } \\
\text { flashover while the other insulator } \\
\text { suffered severe burn marks from the arc }\end{array}$ \\
\hline 25 May & 2 June & $\leq 12$ & 500 & $\begin{array}{l}\text { Circuits on both Paul Allston } 500 \mathrm{kV} \\
\text { lines experienced flashover from } \\
\text { suspected tephra contamination. }\end{array}$ & Flashovers occurred during light rain. \\
\hline
\end{tabular}


Following the May 2008 Chaitén eruption, a 68-km stretch of $33 \mathrm{kV}$ line to Futaleufu township, Chile $(75 \mathrm{~km}$ from the volcano) was coated with fine-grained $(<0.1 \mathrm{~mm}$ particle diameter) rhyolitic tephra of 20 to $>300 \mathrm{~mm}$ in depth in some areas between 2 and 8 May 2008. Local linesmen reported that $10-20 \%$ of the ceramic insulators suffered flashovers after light misty rain between 6 and 9 May 2008. Following inspections, the lines company decided to replace all insulators on the affected stretch of line, as it was too laborious to clean or assess damage to each insulator. Many of the insulators that had suffered flashover were cracked and exhibited burn marks at the base where it screwed onto the supporting metal pin (Fig. 4). Distribution transformers on the circuit were also reported to have suffered flashover damage.

Empresa Electrica de Guatemala (EEGSA) is a distribution supply $(\leq 69 \mathrm{kV})$ company that provides electricity to three of Guatemala's 22 administrative departments. EEGSA reported numerous tephra-related flashovers following the May 2010 eruption of Pacaya. Rain during the eruption added to the risk of tephra contamination of HV equipment, and several faults (flashovers) occurred following $20-30 \mathrm{~mm}$ of coarse-grained tephra fall in Guatemala City. Specifically, there were six $69 \mathrm{kV}$ circuits that endured continual flashovers despite several attempts to re-close the circuits. Of these, Guadelupe lines 1, 2 and 3 were particularly problematic. On 28 May 2010 (the day after the eruption), a 25.88-MW load was shed from a $69 \mathrm{kV}$ circuit causing a 2-h long outage (Wardman et al. 2012a). Despite several reports of flashovers on the system, no burning or physical damage of transmission equipment was noted; thus, no replacement or repair of equipment was required.

\section{Insulator tracking and corrosion}

Leakage current or 'tracking' across contaminated HV insulators causes burning and etching of the insulator surface. This compromises the operational performance of an insulator and, in the case of composite polymers, can reduce the rate of hydrophobic (water repellent) recovery and therefore the dielectric (insulating) properties of the material (Gutman et al. 2011).

September 2009 to March 2010 was a period of particularly frequent tephra fall in the inhabited northwestern areas of Montserrat from the current Soufrière Hills eruption. During this time, a series of tephra falls caused flashovers, tracking and burning of distribution equipment (e.g. insulators, surge arrestors and bushings on pole-mounted transformers) throughout the villages closest to the volcano (Sword-Daniels 2010). Remobilisation of the tephra on Montserrat has also been a problem since the onset of the eruption in 1995, especially in and around the Belham Valley area. Tracking along insulators due to remobilised (and likely leached) deposits has also been observed, suggesting that epiclastic (reworked) tephra may be sufficiently conductive to initiate flashovers and tracking possibly months after deposition.

Corrosion impacts are typically latent effects that are not noticed on Montserrat for several months after a tephra fall. As of 2011, accelerated corrosion of transformer boxes at Isles Bay Hill (located approximately $5 \mathrm{~km}$ WNW from Soufrière Hills volcano) has required construction of additional wooden housing to shield the transformers from tephra contamination (despite the transformers being designed to operate outdoors and withstand inclement weather conditions). When tephra is very fine-grained (e.g. $<0.1 \mathrm{~mm}$ particle diameter), it can penetrate the low-voltage (e.g. $<11 \mathrm{kV}$ ) ground and pole-mounted transformer boxes and is able to build up around the terminals. This has been known to cause the crutch (terminal) of the cables to burn out and/or deteriorate rapidly due to tracking across its surface.

During the January 2011 eruption of Shinmoe-dake, there were no reports of leakage current on KEPC's $66-$ or $6 \mathrm{kV}$ distribution systems. However, the smaller 220- and 110-V distribution systems experienced some reports of leakage current and flashovers. KEPC reported that from the beginning of the eruption until 24 May, there were 54 public reports of corona discharge (electricity leakage with a characteristic crackling or arcing sound) and 29 public reports of flashover disruption of lines from the local transformer to
Fig. 4 a Fine-grained tephra adhered to the underside of a 33 $\mathrm{kV}$ porcelain insulator in Futaleufu, Chile following the 2008 Chaitén eruption. b Underside of a $3 \mathrm{kV}$ porcelain insulator that suffered tephra-induced flashover following the 2008 Chaitén eruption. Note the brown burn mark (centre right) from the high intensity arc during flashover
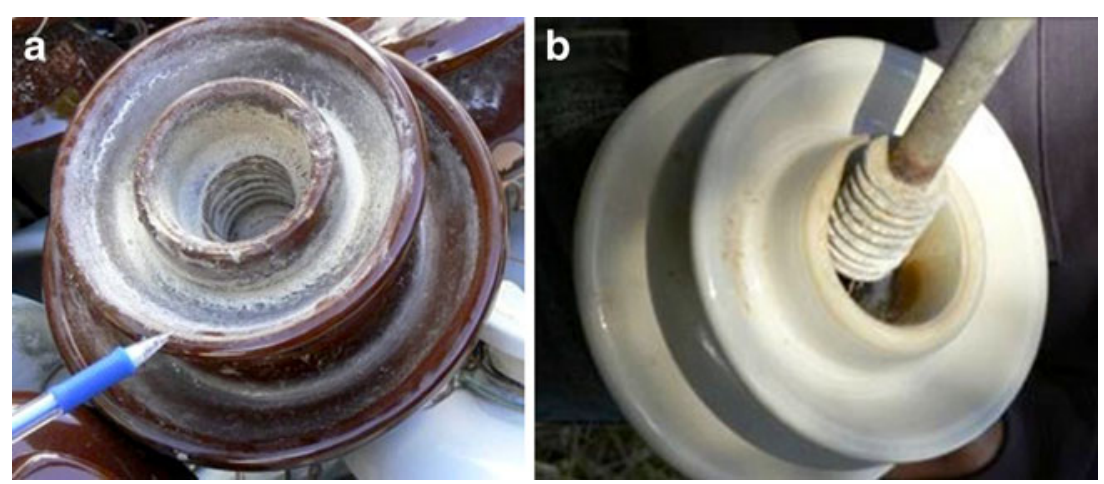
the customer. The majority of these reported impacts occurred at connection points or where the line had been scratched or abraded on the insulator's jacket cover. Over half of the reports occurred between 7 and 10 February 2011 during a period of light misty rain.

\section{Line breakage}

Following a volcano-seismic crisis in 1983-1984, both Tavurvur and Vulcan volcanoes erupted on 19 September 1994, leaving much of the town of Rabaul (17,000 residents) covered in heavy tephra fall, with $2-3 \mathrm{~m}$ covering the southeastern suburbs (Blong and McKee 1995; SMEC International 1999). PNG Power, Ltd. (called PNG Electricity Commission (ELCOM) until 2002) is the primary generator and provider of electricity in Papua New Guinea. ELCOM's power supply was shut-down as a precaution at the start of the 1994 Rabaul eruption (Carlson 1998). The Rabaul Power Station suffered little damage from tephra fall; however, the station was decommissioned and the diesel generators removed due to the extensive damage to the surrounding areas (SMEC International 1999). Falling trees and buildings damaged large sections of the distribution system, including some power transformers.

The same stretch of line that was affected by tephrainduced flashovers between 2 and 8 May in Futaleufu, during the 2008 Chaitén eruption, was impacted again following heavy snowfall on 18 May 2008. The snow, together with the tephra, on lines and poles created a significant load, causing lines to break and poles to collapse. The 6-mm lines were described as looking like '20-mm tubes' with the tephra and snow accumulation. In addition, tephra and snow laden branches collapsed onto lines resulting in further damage. In total, approximately $20 \mathrm{~km}$ of line and poles required replacement.

\section{Controlled outage}

Following contamination of Transpower's HV system during the 1995/1996 Ruapehu eruption, affected circuits were de-energised and cleaning of 18 towers (and insulators) was undertaken on 27 September 1995 by four crews each consisting of four men (Transpower 1995) (Fig. 5). Three strings of insulators were found to have superficial damage (e.g. etching and burning) on their glazed surfaces as a result of flashovers. However, these insulators were not replaced, as, upon visual inspection, it was determined that they had not endured sufficient damage (e.g. cracking or puncturing of the discs) to affect their dielectric strength.

Approximately $50 \mathrm{~mm}$ of tephra fall was received in Esquel, Argentina (110 km from the volcano) over the month of May following the 2008 Chaitén eruption. In this time, the local municipal utility provider reported no damage to the four electricity distribution systems it manages: $132 \mathrm{kV}, 33 \mathrm{kV}$, $220 \mathrm{~V}$ and a three-phase $360 \mathrm{~V}$. However, several shutdowns of the power supply were scheduled to allow cleaning of power transformers, after it was found that tephra accumulation was creating the potential for flashovers.

Substations and switchyards

\section{Tephra-induced flashover}

Several EEGSA substations received $>100 \mathrm{~mm}$ of coarsegrained ( $>1.5 \mathrm{~mm}$ particle diameter) tephra fall out during
Fig. 5 a High-pressure deenergised washing of a power transformer bushing at a substation in Ecuador following the 2010 eruption of Tungurahua. b A linesman cleans tephra from a de-energised $220 \mathrm{kV}$ strain (horizontally strung) insulator located $\sim 15 \mathrm{~km}$ from Ruapehu, New Zealand. C Linesmen cleaning de-energised insulators at a Guayaquil, Ecuador substation after $1-2 \mathrm{~mm}$ of finegrained tephra fell following the 2010 Tungurahua eruption. d Hand-cleaning tephra from a de-energised $220 \mathrm{kV}$ strain insulator after the 25 September 1995 Ruapehu eruption. Photo credits: a Transelectric, b Transpower, $\mathbf{c}$ Transelectric, $\mathbf{d}$ Transpower
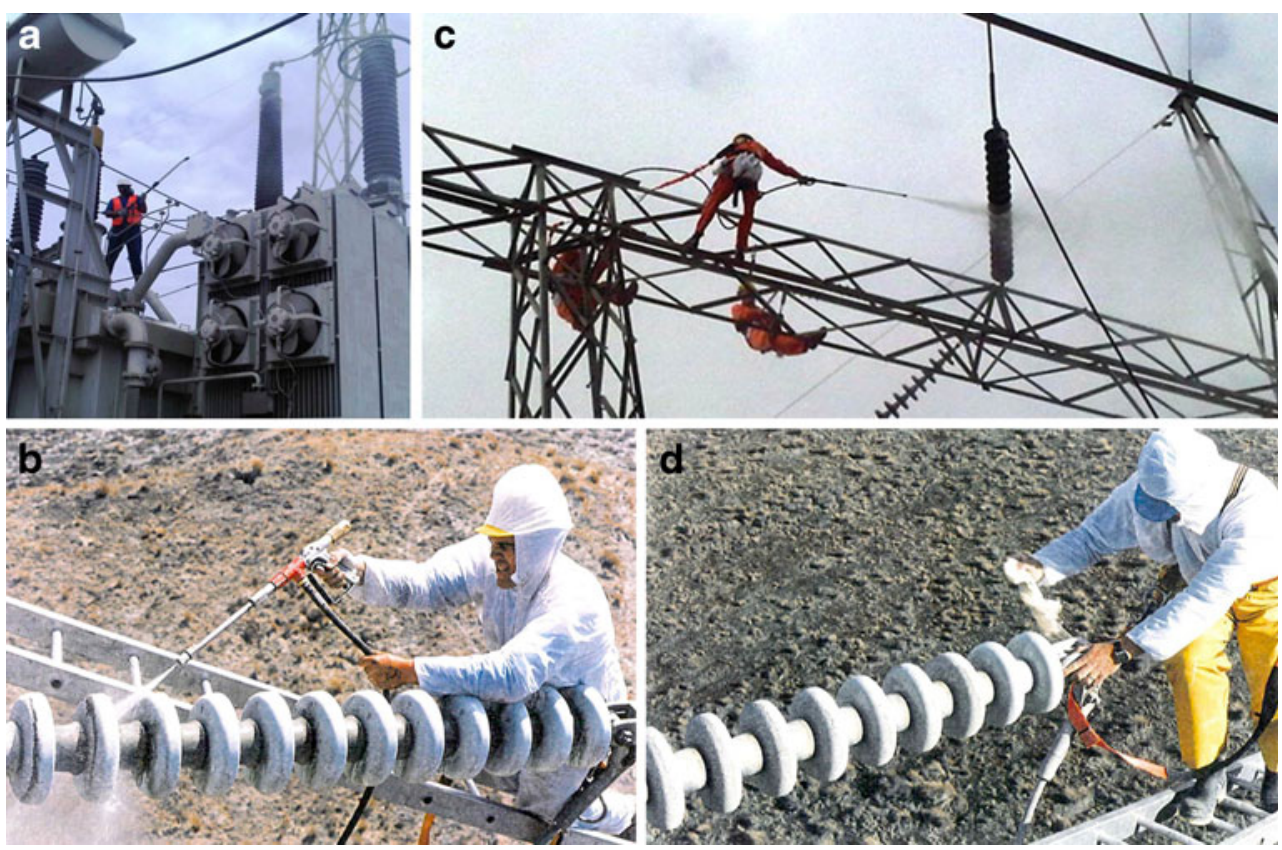
the 27 May 2010 Pacaya eruption, particularly those substations located south of Guatemala City closest to the volcano. The EEGSA substations that received the most tephra fall were scheduled for extensive offline cleaning on 29-30 May 2010. However, the arrival of tropical storm Agatha on 29 May 2010 hindered the cleaning procedure and large amounts of tephra remained on substation equipment during the early hours of the storm. The combination of tephra contamination, together with heavy rain from the storm, caused further faulting (flashovers) on the system, with several interruptions occurring throughout the event (Wardman et al. 2012a).

With the passing of Agatha, it was found that the rains had sufficiently cleaned all substation equipment and none but the Laguna substation (located $\sim 5 \mathrm{~km}$ from the vent), which received $>300 \mathrm{~mm}$ of lapilli-sized tephra, required further cleaning. The power transformers were described by EEGSA staff as being the most problematic and difficult apparatus to wash free of tephra because of the intricate array of cooling fins and sensitive components vulnerable to further damage from abrasion or water/tephra ingress. As a preventive measure, tephra was cleaned from transformer radiator fins to allow sufficient heat transfer and cooling of the apparatus.

\section{Tephra ingress}

Transformer sheds within KEPC substations have openveined windows that allowed ingress of tephra to the buildings during the 2011 Shinmoe-dake eruption. Windows were blocked off at the time of the eruption, but the sheds became too hot several months later in summer, requiring filters to be fitted over the windows. At Miyazaki Power Centre, 48 windows required blocking and later filtering across 14 buildings. At Miyakonojo, 33 windows required blocking and later filtering across 10 buildings.

\section{Decrease in resistivity of substation/switchyard surface rock}

In addition to transmission and distribution system components, tephra from the 18 May 1980 Mt. St. Helens eruption covered surface rock in substation areas causing a major decrease in the ground resistance once wetted by rainfall. This had significant ramifications for step and touch potentials (voltages) present at affected BPA substations. Step potential is the difference in surface voltage between two points $1 \mathrm{~m}$ apart (the step distance) under rated fault conditions, while the touch potential is the difference between the earthing grid voltage and the surface voltage at a point where someone standing on the surface can touch something that is bonded to the earthing grid. A decrease in resistivity of substation gravel means an increase in current passing through the body due to the step and touch potentials and a heightened risk of electrical shock or electrocution. This was identified as a serious danger for technicians entering the area and required de-energising and isolation of equipment before cleaning and/or repair (Buck and Connelly 1980; Nellis and Hendrix 1980; Sarkinen and Wiitala 1981; Rogers 1982).

\section{Controlled outage}

After each of the 1995/1996 Ruapehu tephra falls, electricity generation, transmission and distribution companies routinely cleaned tephra from affected substations. On 17 June 1996, power supply was disrupted in parts of Rotorua city after a powerful flashover occurred across an $11 \mathrm{kV}$ ground mounted distribution transformer bushing at a local substation, caused by tephra and water contamination from a resident hosing tephra from the roof of a neighbouring building (Johnston 1997b). Thus, there was a focussed effort to make sure that all of the $11 \mathrm{kV}$ bus bars and insulation at substations were clear and free of any tephra before power was restored (Bebbington et al. 2008).

Guatemala's Empresa de Transporte y Control de Energia Electrica manages two large $(230 \mathrm{kV})$ substations that were affected by the 2010 Pacaya eruption. These stations (Guate Sur and Guate Este) required offline cleaning shortly before the arrival of tropical storm Agatha. Cleaning involved the sweeping and brushing of tephra from substation apparatus and surrounding yards. Substation equipment was subsequently washed using high-pressure water blasters.

The city of Guayaquil (Ecuador) received 1-2 $\mathrm{mm}$ of very fine-grained $(<0.1 \mathrm{~mm}$ particle diameter) tephra during the May 2010 eruption of Tungurahua, a rare event for the city. The tephra fell during dry conditions, and no instances of flashover were reported. As a precaution, however, substations critical to the continual supply of electricity to Guayaquil were cleaned to prevent tephra-induced failure of HV equipment. To avoid permanent damage to the power transformers from overheating or tephra-induced flashovers, each of the three transformer banks at the Pasquales substation had to be taken offline individually while associated sections of the yard were cleaned. The substation was reenergised once drying of substation equipment (following high pressure water washing) was complete. While remobilization of the tephra was an inconvenience to substation workers for about a month following the initial tephra fall, no further cleaning of equipment was required and no faults (unintended interruptions of supply) were reported (SwordDaniels et al. 2011).

Tephra falls from the 2011 Shinmoe-dake eruption caused no direct impacts to KEPC's transmission lines or substations. However, on 1 February 2011, KEPC shutdown (de-energised) some transmission substations for cleaning. KEPC developed a special hot-stick (insulated 
pole, usually made of fibreglass) with a compressed air line attached for live-line (energised) cleaning of tephracontaminated equipment. A specially designed hot-stick connected to a high pressure water line was also developed (based on the design used for live-line cleaning of sea salt contamination), but due to the uncertain conductivity and therefore flashover potential of the tephra at the time, they took the precaution of only cleaning when de-energised. The Takaharu, Hirose and Sadowara substations were deenergised while tephra was wiped by hand from surfaces with a soft rag where practical and high-pressure water blasters were used to wash apparatus (e.g. power transformers, insulators, circuit breakers, arresters, bus bars, etc.). There were some benefits from rain cleaning, but rainfall intensities conducive to cleaning were unclear.

\section{Analysis of impacts}

The generation, transmission and distribution, and substation components of a modern power system are vulnerable to different and specific tephra-induced impacts, depending on the equipment at each phase of power delivery. A summary of the tephra impacts on the main components of modern power systems is illustrated in Fig. 6 .

We have chosen to use tephra thickness as the most appropriate indicator of tephra hazard intensity when analysing impacts to power systems. We selected it on the basis of its utility for gauging the accumulation of tephra in the field (important for rapid damage assessment), its common use in tephra dispersal models (e.g. Connor et al. 2001; Bonadonna et al. 2005), and its ease of application
Fig. 6 Summary of impacts and management approaches to the a generation, $\mathbf{b}$ transmission and distribution and $\mathbf{c}$ substation and switchyard sectors of the case-study power systems following tephra falls. Tephra-induced insulator flashover is the most common problem arising from contamination of power equipment and therefore poses the greatest threat to the reliability of power supply
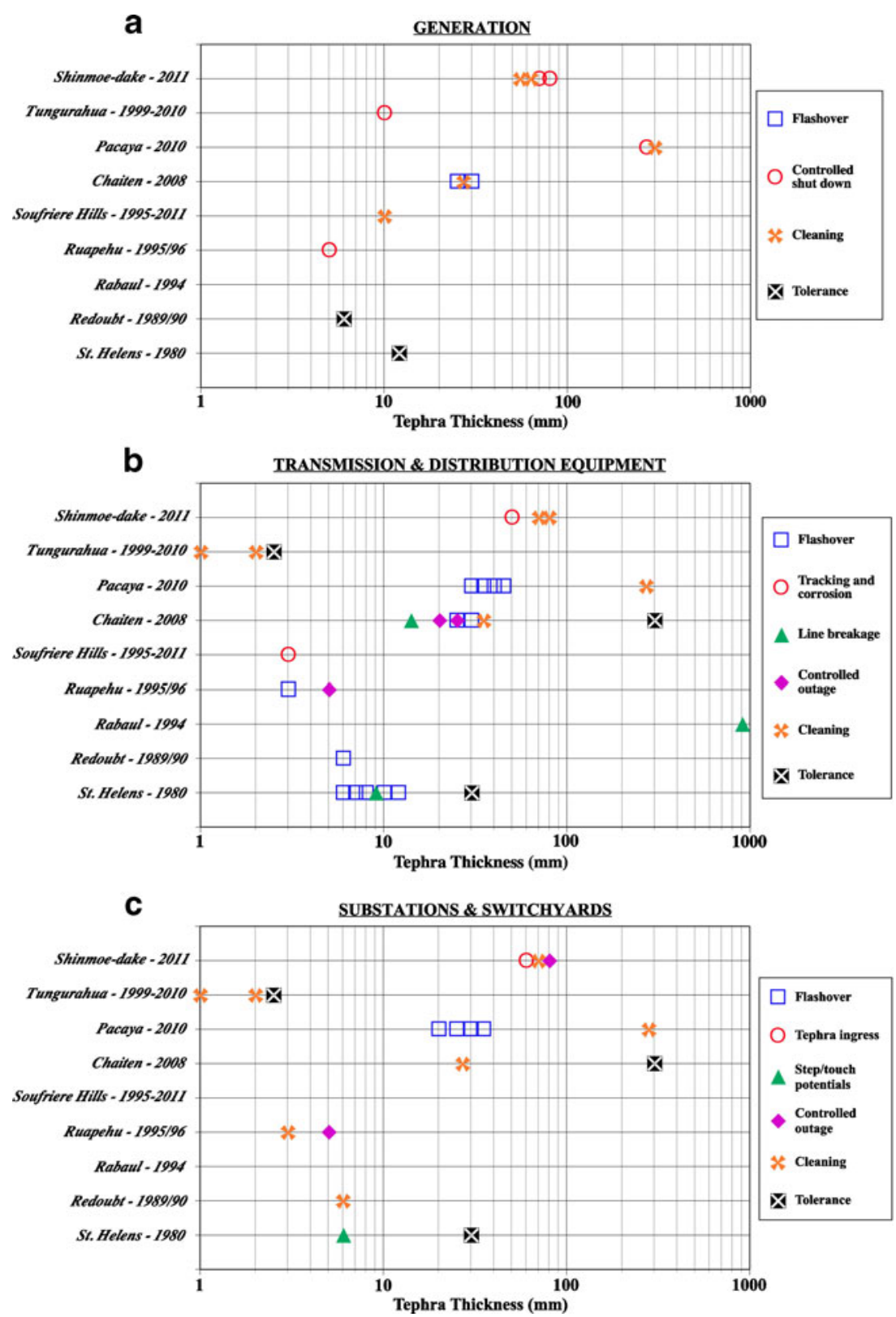
compared to other quantitative methods (e.g. the nonsoluble deposit density, a procedure used by electrical engineers (e.g. Sundararajan and Gorur 1996)). Whilst there are limitations with this approach (e.g. grainsize is a key control of tephra adherence potential, composition is a key control on abrasion, soluble salt load and water holding capacity both influence conductivity, etc.), we found that no other parameter was more suitable. Thus, the following section identifies the most vulnerable system components and, where possible, suggests critical tephra thicknesses for each sector of the modern power system.

\section{Generation}

The most common disruptor of power at generation sites is controlled shut-down of HEP turbines to avoid accelerated wear of submerged components such as runner blades, labyrinth seals, wear rings, band seals, cheek plates and wicket gates. Even HEPs designed to cope with large volumes of sediment, such as the Agoyan Dam in Ecuador, favour bypass of tephra-laden waters over continued operation of the plant, which involves the risk of damaging their turbines.

Critical tephra thicknesses for generation sites are difficult to identify since every dam is designed differently and the exposure of each component to tephra may not be the same as the nominal thickness. For example, at an HEP, the turbines are exposed to suspended tephra in the intake waters, the amount of which is a function of catchment size, flow rate, rainfall, etc., not just tephra thickness experienced in a general area. In light of this, further research should focus on critical turbidity levels rather than tephra thickness before shut-down of a generation facility must occur.

Insulator flashover at generation yards containing step-up transformers can cause cascading impacts, as was seen in Futaleufu, Argentina following the 2008 eruption of Chaitén. If power cannot be transmitted from a generation site due to contamination and subsequent flashover on transformation equipment (e.g. insulators and bushings), then the generated power cannot be transmitted to other sections of the system.

We are unaware of any direct tephra impacts to thermal power plants. However, we highlight that tephra fall is a hazard that could cause generation disruption or shut-down due to blockage of generator air intakes (e.g. as is avoided in Montserrat and was prevented in Japan following the 2011 Shinmoe-dake eruption) and off-site power resources (e.g. emergency lines or generators for back-up power). This is a significant knowledge gap that warrants further research. Similarly, some generation sites rely on HVAC systems to keep sensitive electrical equipment at a maintained temperature (e.g. switching equipment and data centres). HVAC systems are vulnerable to tephra damage (e.g. abrasion of moving parts such as fans), corrosion, and arcing of internal electrical components, and air filter blockage, especially if air intakes are horizontal surfaces, although these impacts have not been recorded.

\section{Transmission and distribution}

According to our analysis, transmission and distribution systems are most vulnerable to insulator flashover from tephra contamination. Insulator flashover can occur with tephra thicknesses as thin as $3 \mathrm{~mm}$ (Ruapehu 1995/1996) provided the tephra is of sufficient conductivity. Additionally, if tephra is not cleaned from insulators immediately following fallout then, with subsequent adsorption of moisture (e.g. mist, fog, light rain, etc.), tephra will adhere strongly (i.e. cement) to all surfaces (making cleaning difficult) and cause latent effects such as corrosion and tracking (as experienced on Montserrat).

Line breakage due to tephra loading was observed following several of the case study eruptions (Mt. St. Helens 1980, Rabaul 1994 and Chaiten 2008). Tephra adherence to lines is highest during wet and freezing conditions, although this is a rarely observed impact (Fig. 6b). Many power companies are liable for maintaining acceptable clearance distances between trees and power lines on both public and privately owned property. Provided these distances are maintained, then the power system should undergo no issues with tephra contamination of nearby vegetation.

\section{Substations and switchyards}

Immediate cleaning of substation equipment has been used as either a reactive or proactive measure against tephra-induced flashover in several of the case studies presented (Mt. St. Helens 1980, Redoubt 1989, Ruapehu 1995/1996, Tungurahua 2010, Shinmoe-dake 2011). Tephra thicknesses received at substations during each of these eruptions have been wide-ranging (refer to Fig. 6c); however, cleaning has commenced with tephra deposits as thin as $1 \mathrm{~mm}$ (Guayaquil, Ecuador following the 2010 eruption of Tungurahua). In every instance where cleaning of substations has taken place, insulator flashover has been avoided and power companies have been successful in maintaining power supply. This highlights the critical importance of substations to the integrity of a power system.

No existing literature or research has documented impacts at switchyards. The lack of sensitive apparatus such as power transformers means that tephra contamination at switchyards will have a lower probability of disrupting power supply. This suggests that switchyards are less vulnerable to tephra-induced impacts than substations; however, more research is needed to verify this claim.

The only evidence of reduction in substation gravel resistivity comes from BPA reports following the $1980 \mathrm{Mt}$. St. 
Helens eruption. However, field data collected from CELEC EP (Ecuador) and EEGSA (Guatemala) suggest that replacement of contaminated substation gravel is not required so long as the tephra and gravel mixture displays a resistivity value $>3,000 \Omega \mathrm{m}$, as prescribed by IEEE Standard 80 (2000).

\section{Tolerance}

Instances of tolerance to tephra contamination have been noted in nearly every case study but are drastically underreported. From the data, it appears that many substation components mentioned in this paper such as disconnect switches, bus bars, circuit breakers, capacitors and metering transformers (voltage and current transformers used to monitor power quality) are less vulnerable to tephra fall than other apparatus highlighted in this study (e.g. power transformers). However, the lack of data does not mean that these components are completely tolerant to tephra-induced impacts but rather implies that further investigation is needed to quantify their vulnerability to tephra hazards.

\section{Probabilistic assessment of insulator flashover}

Our review has shown that tephra-induced insulator flashover can occur in all sections of a modern power system and is the most common impact from tephra contamination. Factors contributing to tephra-induced flashover are shown in Fig. 7. Given the interdependencies between electrical, volcanological and environmental factors that influence tephra-induced insulator flashover potential, it is difficult to make a reliable prediction whether flashover will occur during a particular tephra fall. However, from the case studies summarised here, simple probabilistic analysis can be undertaken to produce a function that estimates the likelihood of a flashover occurring causing system disruption.

We have used an event tree to conceptually illustrate the sequence of events required for tephra-induced insulator flashover to occur (Fig. 8). Each branch of the tree leads from a necessary prior event to a more specific outcome (e.g. from an eruption to a tephra fall). Several of the events are controlled by external factors, such as conditions at the volcano (eruption style), environmental conditions (wind direction and precipitation), design of the power system, prior contamination of system components, etc. Such information requires input at the time of risk assessment for a particular scenario. However, considering the lack of quantified data for events 3-5 (Fig. 8), our compiled review dataset of flashovers and tolerances allows us to create a fragility function that estimates the conditional probability of a flashover occurring for different tephra thicknesses. This simple, first-order approach is designed to aid system operators in assessing the allowable accumulations of tephra before initiating mitigation strategies.

In this instance, the limitations in the available data (discussed below) mean that we have chosen to only consider one type of impact (flashover across one cylindrical insulator or insulator string), the tephra thickness at the time of flashover and the presence of moisture in the tephra upon flashover. By choosing to simplify in this manner, we focus only on the significant factors that dictate whether flashover will occur. However, this approach does not account for other influences such as detailed environmental conditions, prior contamination (e.g. salt spray), and insulator model, composition and orientation as these are, in most cases, unknown.

\section{Derivation of the fragility curve}

Fragility functions give the conditional probability of exceeding a specific damage state as a function of the intensity of the hazard present (e.g. tephra thickness). They are typically based on empirical observations of a particular system's or component's performance at varying levels of hazard intensity. For the purpose of this study, fragility functions can be defined as mathematical algorithms that relate the intensity of
Fig. 7 Flow chart illustrating the many variables influencing tephra-induced insulator flashover (adapted from Johnston 1997b)

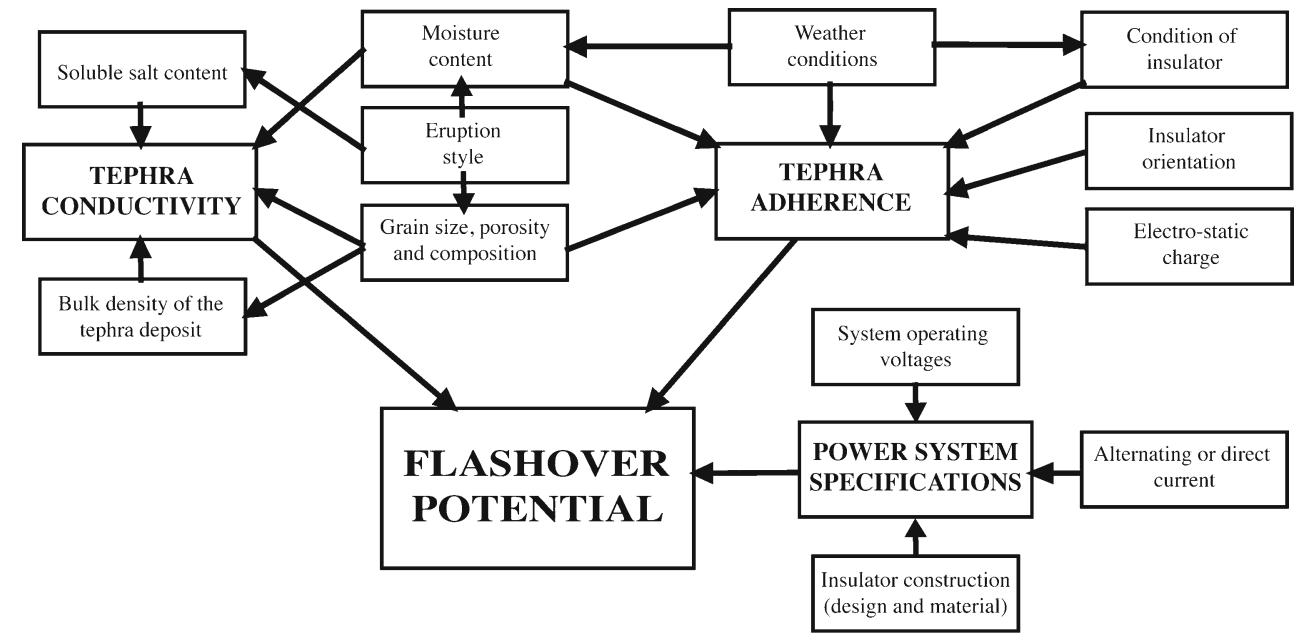


Fig. 8 Event tree showing the sequence leading up to tephrainduced flashover. At present, values for the likelihood of each event occurring at each node are not available to hazard managers or power system operators. The development of fragility functions will help to populate event trees such as this one with more robust data for interpretation

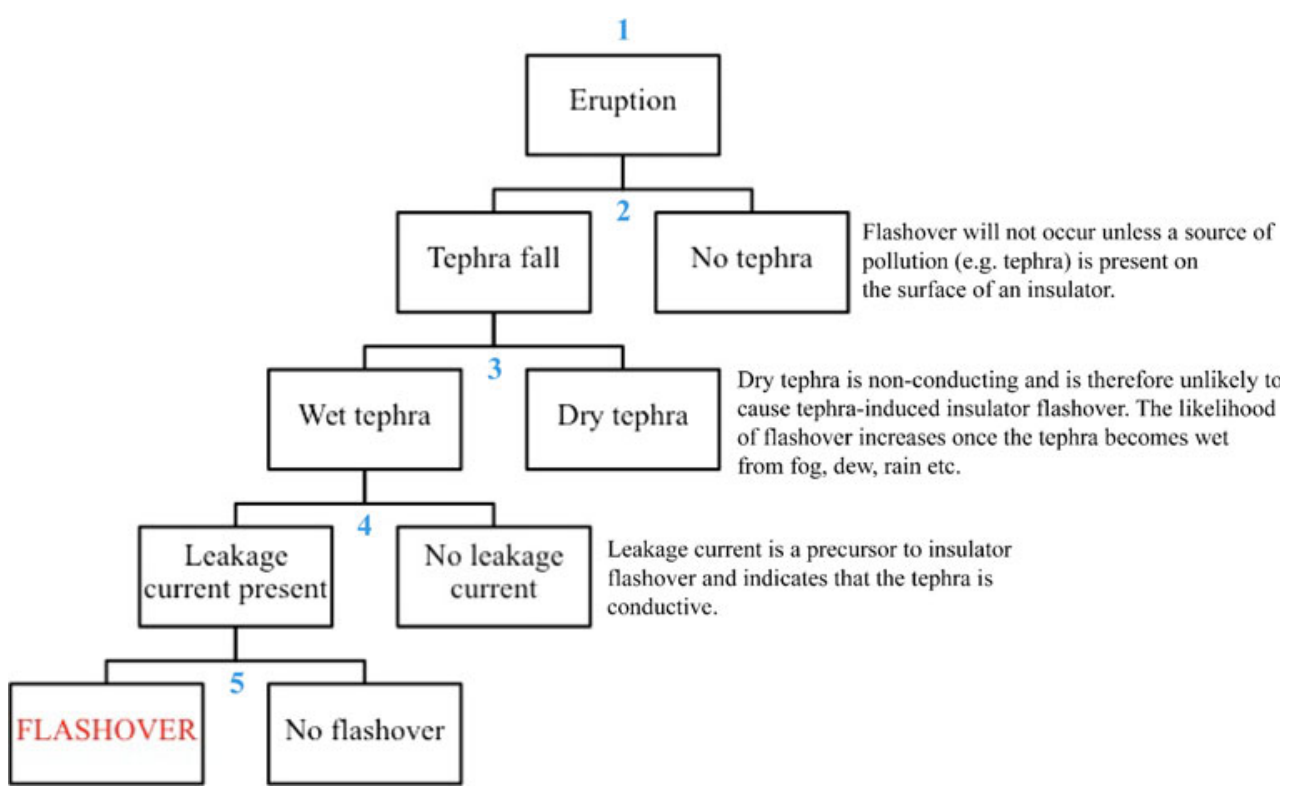

a hazard (e.g. tephra fall) with a certain degree of loss or damage (e.g. 0-100\%). Few studies in the field of volcanic hazards have utilised fragility functions, mainly due to the lack of quantitative damage or loss data. Limited examples include estimating the collapse probability of residential buildings from tephra (e.g. Blong 2003; Spence et al. 2005) and predicting building damage from pyroclastic flows (e.g. Baxter et al. 2005). While fragility functions have been used sparingly in probabilistic volcanic risk analysis, their usefulness has been demonstrated in other disciplines, notably in earthquake engineering to determine the probability of building failure at different ground shaking intensities (e.g. Rossetto and Elnashai 2003; Akkar et al. 2005; Porter et al. 2007).
We can assume that because insulator flashover is a mutually exclusive event and HV insulators are designed to prevent the transfer of electricity from transmission and distribution equipment to earthed (bonded with the ground) apparatus, insulator flashover can be considered a $100 \%$ failure in performance. Conversely, instances of tolerance signify $0 \%$ failure (Fig. 9).

As this is the first study of its kind to create a fragility function for HV insulation exposed to tephra fall, and given our limited binary dataset, we have selected a logarithmic function to provide an estimate for the probability of flashover across a single cylindrical insulator or insulator string at different thicknesses of either wet or dry tephra. After plotting the data, a line of best fit was applied and the

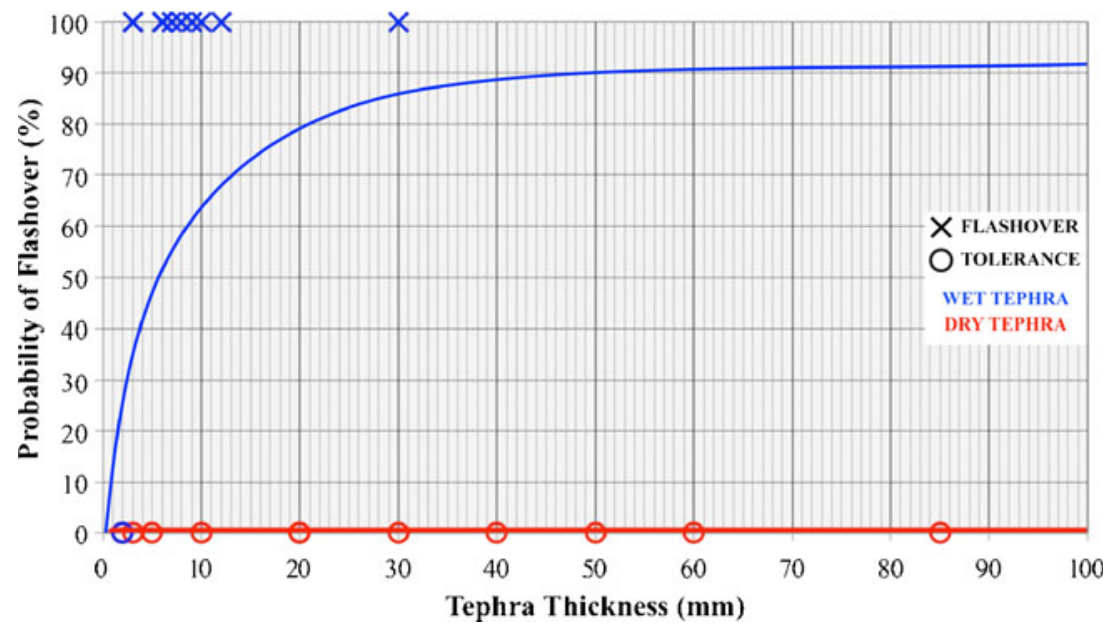

Fig. 9 Logarithmic fragility curves showing the probability of tephra induced flashover as a function of wet or dry tephra thicknesses. Data are derived from systems that have either experienced flashover or exhibited tolerance to tephra fall, or both. Insulator flashover is considered a $100 \%$ failure in performance while instances of tolerance signify $0 \%$ failure. However, these data have only been added to this figure as a guide (i.e. they are not plotted); rather, the blue and red fragility curves (wet and dry tephra, respectively) estimate the probability of flashover based on the discrete end member data points. Two anomalous wet samples at 2 and $300 \mathrm{~mm}$ (not shown) represent the only two recorded instances where wet tephra did not cause insulator flashover 
resulting curves are presented in Fig. 9. Results suggest that dry tephra will not cause flashover but increasing thicknesses of wet tephra on insulators will increase the likelihood of flashover. The generated curves and data trends agree with our observations from existing literature and experiences in the field.

There are limitations to this approach. Perhaps, the most significant is the limited available dataset. Despite our best efforts, the field data do not acknowledge the many instances of tolerance on a power system during a single flashover event. For example, one insulator string may flashover while many dozens of strings that received similar accumulations of tephra elsewhere on the same circuit exhibit tolerance (do not fail). Furthermore, the data often do not indicate whether some of the flashovers occurred during the tephra fall or some time after the initial fallout (with subsequent rains or humid conditions). These are limitations of the retrospective, qualitative data collection methods employed. Nevertheless, the proposed model is intended to be a basic tool for volcanic risk assessment and serves as the basis for future analogue laboratory tests where more robust data can be collected to refine the model.

\section{Mitigation}

Measures taken by power system operators in the aforementioned case studies to manage the risk of tephra impacts have been largely reactive. That is, operators did not specifically strengthen or design their power systems to mitigate tephra fall hazards. Throughout our research, we found that system operators were largely unaware of the potential issues arising from tephra contamination and, in many cases, were surprised at the onset of problems. Warnings from volcanic scientists were either unavailable or unheeded, creating a lack of situation awareness. This highlights the need for system protocols that emphasise partnership and knowledge transfer between volcanic scientists and system operators. With the start of tephra fall, the majority of power system operators focussed on protecting the critical components of the system. It is clear from their actions that generation sites and substations are the most important nodes of a transmission and/or distribution system.

\section{Mitigating the risk}

Mitigation actions immediately prior to, during and after tephra fall have two basic purposes: (1) preventing or limiting tephra entering systems or enclosures, and (2) effective and efficient removal of tephra to prevent or reduce damage. Maintaining system infrastructure in a good state of repair and in clean condition is considered the best practise for longterm mitigation of tephra fall hazards (Wilson et al. 2009).
There are four strategies to manage the risk of power system impacts from tephra fall hazards (adapted from AS/ NZS ISO-31000 (2009)):

1. Avoid the risk by deciding not to start/continue with the activity that gives rise to the risk.

2. Remove the risk source.

3. Change the likelihood.

4. Retain the risk by informed decision.

The following sections provide some key mitigation strategies according to each of the four risk management principles. In most cases, the suggestions addressed herein consider the range of known tephra impacts and are based on our current knowledge. Ideally, they should be verified through trial before implementation. Further information on the application of these methods can be found in Table 3 .

Avoiding the risk

De-energising/shutting-down until tephra fall has subsided

The most effective method of preventing tephra-induced impacts is to avoid the risk altogether by shutting down, closing off and/or sealing off equipment until the tephra is removed from the immediate environment. However, in many cases, this is not practical or acceptable. For example, de-energising a critical substation (e.g. one that provides the only feed to an area) to possibly avoid several thousand dollars of damage to a particular piece of equipment may disrupt service resulting in losses of millions of dollars. Conversely, if a system operator chooses to retain supply during heavy tephra fall and a power transformer suffers damage, then both service and component losses will be incurred. Thus, it can be safer to de-energise, clean contaminated apparatus and bear service losses than to continue operating with an unquantified risk. However, the decision to de-energise will also depend on the importance of the circuit(s) or apparatus in providing power to other critical infrastructure (e.g. emergency supply to nuclear facilities, other crucial nodes of the system, water supply, primary industry, etc.). In all instances, communication of decision making should be made to clients as rapidly and openly as possible to enable them to plan for disruptions.

The difficulty noted in making these decisions highlights the need for further quantification of system component vulnerability so that decisions made by system operators to mitigate tephra impacts are effectively informed.

\section{Land-use planning}

Removing the risk source (the volcano) is not a feasible option. However, power companies can revise their land-use planning to re-route circuits and stations so that they do not 


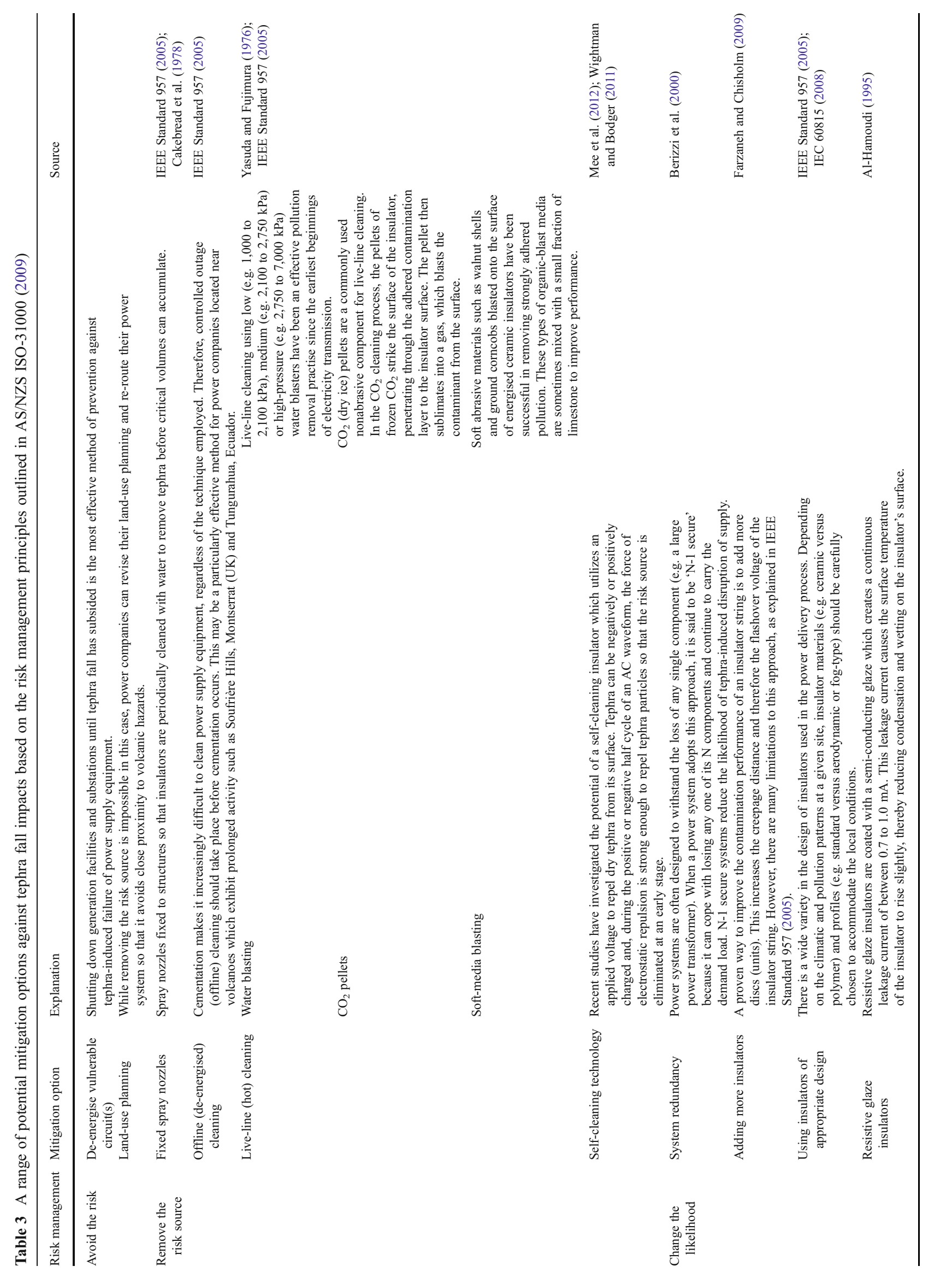




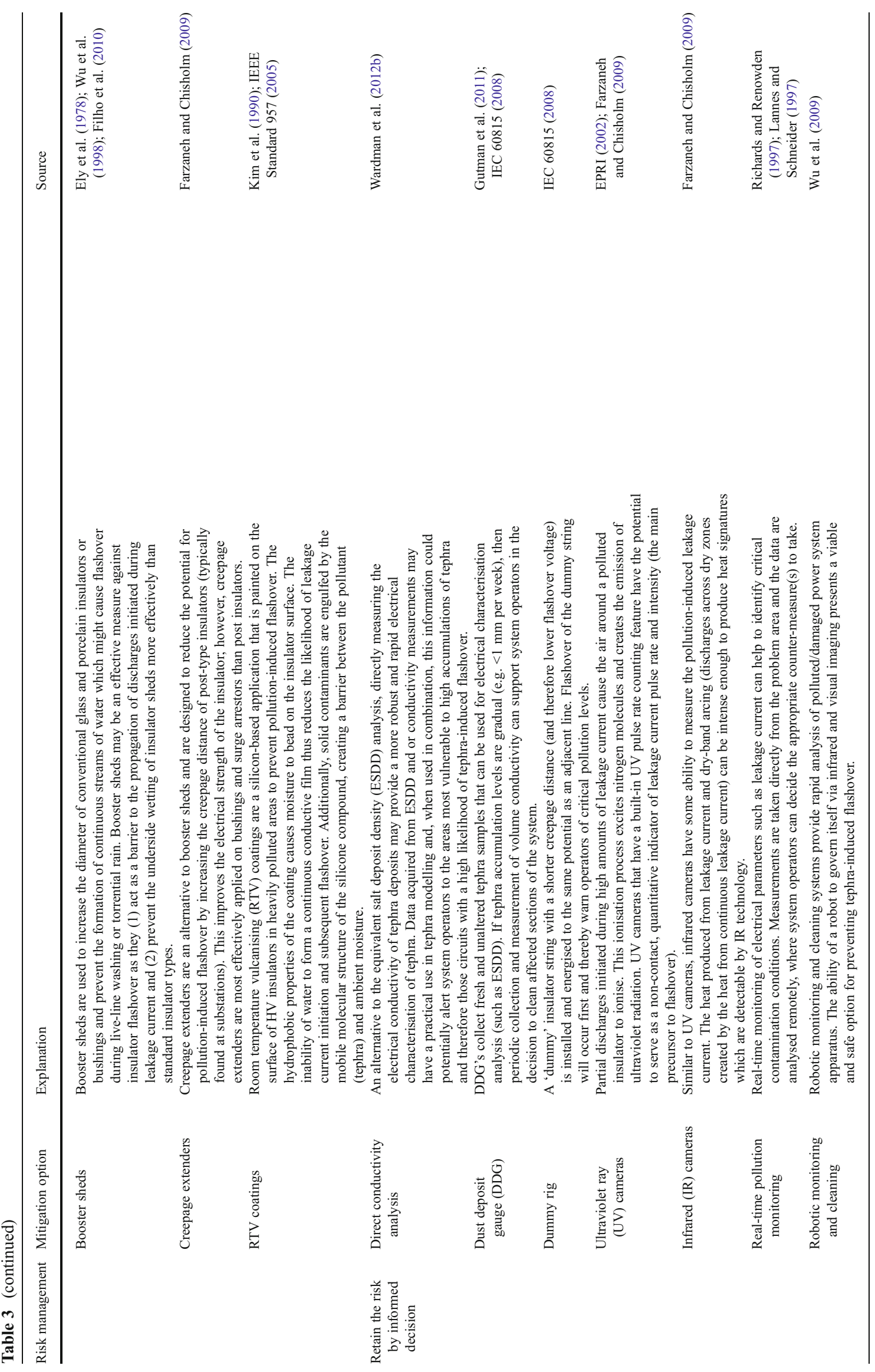


lie proximal to or in the typical downwind path of a volcano. Whilst this is an extreme and potentially expensive measure, it is an effective one that has particular relevance for areas that endure frequent tephra falls such as those near Tungurahua or Soufrière Hills.

Removing the risk source

\section{Live-line cleaning}

Live-line maintenance is a method used by linesmen to clean and/or repair power lines without disrupting power to parts of the system and is an effective way to remove tephra (the risk source) from power apparatus. No official cleaning guide or standard exists which outlines the most appropriate methods to clean tephra from power system components; however, the methods employed by CELEC EP following the 2010 Tungurahua eruption or KEPC during the 2011 Shinmoe-dake eruption demonstrate the effectiveness of simple techniques and routine practises that can be easily adopted by any electricity company looking to mitigate tephra-induced impacts at substations. For liveline cleaning, an appropriate procedure is as follows (refer to IEEE Standard 957 (2005) for further information on safe and effective live-line cleaning practises):

1. All cleaning personnel should be required to wear a facemask and eye protection in addition to any personal protection equipment required by the power company.

2. Compressed air cleaning (with or without a nonabrasive component) can be used to remove initial large amounts (e.g. $>3 \mathrm{~mm}$ ) of tephra. If using compressed air alone, then a pressure of $210 \mathrm{kPa}$ or less $(\leq 30 \mathrm{psi})$ should be applied to avoid a sandblasting effect on glazed ceramic surfaces such as insulators and bushings and other sensitive equipment. Care should also be taken to avoid blowing tephra into other parts of the substation or onto lines that have already been cleaned.

3. A set of insulated tools for wiping, brushing and washing tephra from energised equipment should be devised (e.g. as outlined in IEEE Standard 957 (2005)).

a. For example, hot-sticks (designed appropriately for the component's rated voltage) fitted with brush heads or rags (typically made of burlap) work well for 'hotwiping' tephra from substation equipment (e.g. insulators, bushings, switches, busbars, circuit breakers, etc.).

4. Depending on how strongly the tephra has adhered to equipment, low-, medium- or high-pressure (e.g. 1,400$7,000 \mathrm{kPa}$ ) water blasting should be used to thoroughly rinse away any residual tephra. If the tephra has become heavily cemented to insulators, then soft-media blasting may be an effective alternative (refer to Table 3 for more information).
5. A routine and continuous cleaning programme should be maintained until the threat of airborne tephra contamination is over (including that of remobilised tephra deposits).

\section{Offline cleaning}

For de-energised cleaning, the following procedure has been adapted from methods employed by Transpower (New Zealand), CELEC EP (Ecuador) and KEPC (Japan) and from those outlined in IEEE Standard 957 (2005):

1. All substation equipment must be de-energised and earthed prior to cleaning.

2. All cleaning personnel should be required to wear a facemask and eye protection in addition to any personal protection equipment required by the power company.

3. Depending on the state of the tephra (e.g. wet or dry), transformer bushings and radiator fins should be cleaned by hand using soft rags followed by highpressure washing (see Fig. 5a).

4. Insulators, bus bars, circuit breakers, metering transformers and other critical apparatus should be cleaned by hand in a similar procedure as that used for transformers. Extra care should be taken to ensure that all surfaces are cleaned, including the undersides of insulators. Additional materials, such as wet or paraffinsoaked cloths, steel brushes or steel wool, may be needed for insulators with strongly adhered tephra deposits.

5. If tephra deposits are strongly cemented to ceramic surfaces (insulators and bushings), then a mild (and inert) solvent or detergent (e.g. OMYA brand products) can be applied and wiped clean using soft brushes, rags, paper towels or non-abrasive nylon pads. Steel wool can also be used when other cleaning tools are ineffective; however, caution should be exercised to avoid abrading ceramic surfaces and remove all metal particles left by the steel wool. No solvents should be applied to polymer insulators unless advised by the manufacturer.

6. CELEC EP noted that contacts on disconnect switches (electrodes) are especially difficult to clean and may require scrubbing with a rough sponge or nylon pad to remove the contact grease in which tephra becomes embedded.

7. The substation can be re-energised once all substation equipment has been dried using soft rags.

The above methods can be easily adapted for transmission and distribution lines and insulation. Alternative cleaning methods for transmission and distribution system components (energised and de-energised) are provided in Table 3. 
Changing the likelihood

\section{System redundancy}

The probability of two or more independent faults taking place on a power system simultaneously is very low (Berizzi et al. 2000). However, to account for this low-risk (but high consequence) event, power systems are often designed to withstand loss of individual lines or elements such as power transformers. When a power system adopts this approach, it is said to be ' $\mathrm{N}-1$ secure' because it can cope with losing any one of its $\mathrm{N}$ components and continue to carry the demand load. N-1 secure systems reduce the likelihood of tephrainduced disruption to power supply but, however, do not consider the far-reaching effects of tephra that can cause numerous faults over hundreds of square kilometres of assets.

\section{Insulator modification}

$\mathrm{HV}$ insulators designed to operate in polluted conditions come in a range of different shapes and sizes and are constructed from several different materials (IEC-60815 2008). Depending on the climatic and pollution patterns at a given site, insulator materials (e.g. ceramic versus polymer) and profiles (e.g. standard versus aerodynamic or fog-type) should be carefully chosen to accommodate the local conditions. Adapting the types of insulators used in volcanoproximal zones could reduce the likelihood of flashover, minimize the effects of tracking and leakage current, and ultimately improve system reliability.

A logical way to improve insulator contamination performance is to increase the number of insulators (or length of a single insulator) on a line or substation. Contamination flashover performance tends to scale linearly with creepage distance, so adding three new discs to a string of ten identical ones can improve the flashover strength by $30 \%$ (Farzaneh and Chisholm 2009). However, this approach is not without limitations, including a loss in acceptable line clearance distance and the difficulties in changing intricate types of insulators such as those found at substations.

Retaining the risk by informed decision

\section{Doing 'nothing'}

In the case of minor tephra falls, it may be more economical for power companies to retain the risk by leaving small deposits (e.g. $\leq 3 \mathrm{~mm}$ ) on insulators, lines and structures to be cleaned naturally by rain and wind action. The informed decision to leave tephra on power hardware should depend on the electrical conductivity of the tephra, a factor that is largely influenced by the amount of ionic content in the form of soluble salts present on the tephra's surface (refer to Wardman et al. 2012b for more information). In the case of substations, however, heightened attention to these facilities with only small accumulations of tephra (e.g. $1 \mathrm{~mm}$ in the case of the 2010 Tungurahua eruption) suggests that immediate cleaning is essential to ensuring the safe and reliable provision of electricity to society.

\section{Real-time pollution monitoring}

Real-time pollution monitoring can provide some indication of contaminated conditions on energised insulators. For example, analysis of leakage current and/or partial discharge on contaminated insulators can warn system operators of critical pollution levels prior to flashover (Farzaneh and Chisholm 2009).

The resistivity (conductivity) analysis developed by Wardman et al. (2012b) is a rapid field method that can be used to measure the electrical properties of tephra in space and time. If conductivity values are known before substantial deposits of tephra can accumulate (e.g. $>1 \mathrm{~mm}$ ), then tephra fall forecasts can be combined to provide an early indication of which facilities and sections of lines may be at the greatest risk of impacts, such as insulator flashover.

\section{Use of the fragility model to forecast flashover}

When opting to retain the risk, there is significant uncertainty about failure thresholds. Our fragility model comprises impact data from various different eruptions and thus a range of different tephra falls. The fragility function therefore accounts for the many variations in electrical conductivity (and therefore flashover potential) present in each case-study tephra. When used in combination with realtime pollution monitoring and the resistivity analysis developed by Wardman et al. (2012b), a more robust indicator of tephra-induced flashover is produced. The addition of nearreal-time information provided by volcanic scientists such as tephra fall dispersal (isopach maps) and fall rates will further strengthen power system operator decision support.

\section{Response plan}

Heightened operational readiness, efficient monitoring and impact assessment of any disruption or damage are key elements of good risk mitigation practise. Response plans should include procedures to monitor warnings from volcano observatories (including notification of eruptions and potential tephra falls), reducing or shutting down operations, and accelerated maintenance and tephra-clean-up operations, including access to filters and cleaning/disposal equipment. 
Based on the lessons learned from our review, the following response plan will aid power system operators in preparing for and mitigating impacts from tephra fall hazards:

1. Secure the health and safety of staff. Goggles and masks are essential for protection, but so are safe operating procedures, as horizontal surfaces (e.g. roads and ladders) can become very slippery.

2. System operators should maintain situation awareness by actively monitoring warnings and advice from local volcano observatories or relevant agencies to obtain the most up-to-date scientific alert levels, eruption warnings, tephra fall maps and forecasts. Operators should establish and maintain these connections during noncrisis periods.

3. Prepare a system for cleaning equipment before, during and after (e.g. for remobilised deposits) the event. This should include an estimate of the number of people and equipment required which can be predetermined by the magnitude of the tephra fall. When problems arise (e.g. notification of leakage current or corona discharge), a rapid response can be made.

4. Monitor the volcanological information from hazard scientists/agencies (e.g. tephra fall forecasts, isopach maps, fall rates, etc.), the power dynamics of the system (e.g. voltage fluctuations, leakage current, etc.) and the conductivity of the tephra (by equivalent salt deposit density (ESDD) analysis or via the conductivity method proposed by Wardman et al. 2012b). Based on these observations, make informed decisions on whether to continue supplying power to vulnerable sections of the system.

5. Implement a mitigation strategy (as detailed in Table 3) if the benefits of maintaining power supply outweigh the financial consequences of de-energising all or part of the system.

\section{Future directions}

There is need for comprehensive standardised documentation of tephra-induced impacts and cases where preventative measures have been employed and subsequent success in maintaining constant supply during and/or after a volcanic eruption has been achieved. Knowledge of tephra fall impacts and mitigation is very limited, so any systematic assessment from technical experts is extremely valuable. In particular, it would be useful to know the percentage of adverse impact occurrence on the system as a whole. For example, in order to better define fragility functions, we must know what percentage of insulators flash over on a given stretch of line that receives similar thicknesses of tephra fall. Identification of those components most often affected by tephra contamination together with further development of cleaning and mitigation strategies will undoubtedly strengthen the resilience of electric power systems.

Further research is needed to design power systems that are resilient to tephra fall hazards. Proactive and reactive response plans, cleaning methods, volcanic and electrical monitoring techniques, and mitigation strategies must be furthered and synthesised to provide adequate decision support for system operators. Additionally, tephra samples intended for electrical analyses such as conductivity and ESDD should be collected from specific impact sites to ensure accurate representation of the electrical properties that have contributed to the impact. These are vital first steps in working towards providing reliable power supply to society during tephra falls.

\section{Conclusions}

We have identified the key sources of risk, areas of impacts, events and their causes, and their potential consequences for power systems exposed to tephra fall. The following conclusions can be drawn from this study:

1. Case studies from around the world highlight the vulnerability of power systems to tephra fall hazards and emphasise the need for more robust planning and mitigation strategies against tephra contamination. Tephra can disrupt power supply in the following ways:

a. Tephra-induced flashover on HV insulators or transformer bushings.

b. Controlled outages for tephra cleaning.

c. Accelerated wear of HEP turbines (e.g. runner blades, labyrinth seals, wear rings, band seals, cheek plates and wicket gates) and moving components at generation and substation facilities (e.g. transformer fans).

d. Tephra ingress into HVAC systems which can block intakes causing reduction of functionality or failure of sensitive electronic equipment such as switching and data acquisition systems.

e. Line breakage, bridged phases, and damage to towers and poles due to tephra loading directly onto structures or by causing vegetation to fall onto lines.

f. Deterioration of apparatus due to corrosion and degradation of insulation from burning and etching caused by 'tracking' and leakage current (initiated by conductive deposits of tephra).

2. The most common cause of power generation, transmission or distribution interruption arises from tephrainduced insulator flashover. Dry tephra will not cause 
flashover. Once the tephra becomes wet, however, the likelihood of insulator flashover increases significantly, prompting immediate evasive action from power system operators.

3. We have developed a fragility function for estimating the probability of flashover across an insulator at a range of dry or wet tephra thicknesses. Whilst it has a number of limitations, our model represents a first-order approach to probabilistically estimating the thickness of wet tephra required to cause tephra-induced insulator flashover.

4. We propose a number of untried but potential mitigation strategies to be used during and after a tephra fall. The most effective mitigation strategy against tephra impacts is shutting down substation and generation facilities until the tephra has been effectively removed from the immediate area.

a. There are no guidelines for cleaning tephra from insulators or other exposed electrical infrastructure. This is a key knowledge gap.

5. Substations and generation sites have many critical components and, as a whole, represent microsystems within a larger power system. Future work should therefore look to quantify the vulnerability of all outdoor components involved in providing power supply to society.

6. Detailed and standardised reporting of power system failure and resiliency during or following tephra fall is crucial to improving our understanding of the processes of tephra-induced impacts and enhance the effectiveness of methods used within probabilistic volcanic risk assessment.

Acknowledgments The authors wish to thank Transpower New Zealand, Ltd. (Wardman, Wilson), Ministry of Science and Innovation Grant C05X0804 (Wilson, Cole), and the Earthquake Commission for funding support. We thank Victoria Sword-Daniels for review of an early draft of the paper. We thank Grant Heiken, Kim Genareau and Bill Rose for their insightful and supportive reviews of this manuscript and Steve Self as editor. Finally, thank you to the power system operators and personnel who gave up their time to provide invaluable information for this study.

\section{References}

Akkar S, Sucuoğlu H, Yakuta A (2005) Displacement-based fragility functions for low and mid-rise ordinary concrete buildings. Earthquake Spectra 21(4):901-927

Al-Hamoudi IY (1995) Performance of HV insulators under heavy natural pollution conditions. Proceedings of the Seventh International Conference on Transmission and Distribution Construction and Live Line Maintenance ESMO-95, 29 Oct-3 Nov, pp 25-31
Australian/New Zealand Standards (AS/NZS) ISO 31000 (2009) Risk management - principles and guidelines. Jt Australian New Zealand Standard, superseding AS/NZS 4360: 2004, 37 p

Baxter PJ (1990) Medical effects of volcanic eruptions. I. Main causes of death and injury. Bull Volcanol 52:532-544

Baxter P, Boyle R, Cole P, Neri A, Spence R, Zuccaro G (2005) The impacts of pyroclastic surges on buildings at the eruption of the Soufrière Hills volcano, Montserrat. Bull Volcanol 67:292-313

Bebbington M, Cronin S, Chapman I, Turner M (2008) Quantifying volcanic ash fall hazard to electricity infrastructure. J Volcanol Geotherm Res 177:1055-1062

Berizzi A, Merlo M, Zeng Y, Marannino P, Scarpellini P (2000) Determination of the N-1 security maximum transfer capability through power corridors. Proceedings of the Power Engineering Society Winter Meeting, 23-27 Jan. IEEE 3:1739-1744

Billinton R, Allan R (1988) Reliability assessment of large electric power systems. Kluwer Academic Publishers, Boston

Blong RJ (1984) Volcanic hazards: a sourcebook on the effects of eruptions. Academic, Australia

Blong R (2003) Building damage in Rabaul, Papua New Guinea, 1994. Bull Volcanol 65:43-54

Blong R, McKee C (1995) The Rabaul eruption 1994: Destruction of a town. Natural Hazards Research Centre, Macquarie University, Australia $52 \mathrm{p}$

Bonadonna C, Phillips JC, Houghton BF (2005) Modeling tephra sedimentation from a Ruapehu weak plume eruption. J Geophys Res 110(B8) B08209, AGU. doi:10.1029/2004JB003515

Buck CR, Connelly JW (1980) Effects of volcanic ash on resistivity of standard specification substation crushed rock surfacing under simulated rainfall. Bonneville Power Administration, Laboratory Report ERJ-80-50, 20 p

Cakebread RJ, Brown HJ, Dawkins RB (1978) Automatic insulatorwashing system to prevent flashover due to pollution. Proc Inst Electr Eng 125(12):1363-1366

Carlson, L. (1998) Planning the restoration of Rabaul: Risk, compromise and mitigation. Proceedings of the IEPNG Conference '98, Engineering in Natural Disasters: Survival, Relief and Restoration, 25-27 Sep, Rabaul, Papua New Guinea, pp 49-58

Connor C, Hill B, Winfrey B, Franklin N, Femina P (2001) Estimation of volcanic hazards from tephra fallout. Nat Hazards Rev 2 (1):33-42

Cronin SJ, Neall VE, Lecointre JA, Hedley MJ, Loganathan P (2003) Environmental hazards of fluoride in volcanic ash: a case study from Ruapehu volcano, New Zealand. J Volcanol Geotherm Res 121:271-291

Electric Power Research Institute (EPRI) (2002) Guide to corona and arcing inspection of overhead transmission lines, EPRI Rep 1001910, 2002

Ely CHA, Lambeth PJ, Looms JST (1978) The booster shed: prevention of flashover of polluted substation insulators in heavy wetting. IEEE Trans Power Appar Syst PAS-97 (6):2187-2197

Farzaneh N, Chisholm W (2009) Insulators for icing and polluted environments. Wiley-IEEE Press, Picataway

Filho OO, Cardoso JA, de Mello DR, de Azevedo RM, Carvalho SG (2010) The use of booster sheds to improve the performance of $800 \mathrm{kV}$ multicone type insulators under heavy rain. Proceedings of the 2010 International Conference on High Voltage Engineering and Application (ICHVE), 11-14 Oct, pp 485-488

Global Facility for Disaster Reduction and Recovery (GFDRR) (2011) Volcano risk study: Volcano hazard and exposure in GFDRR priority countries and risk mitigation measures. NGI Report 20100806, 3 May 2011

Gutman I, Djurdjevic I, Eliasson AJ, Söderström P, Wallin L. (2011) Influence of air-borne ashes on outdoor insulation. Proceedings of the SC B2 Conference, Reykjavic, Iceland, $6 \mathrm{p}$ 
Hall ML, Robin C, Beate B, Mothes P, Monzier M (1999) Tungurahua Volcano, Ecuador: structure, eruptive history and hazards. J Volcanol Geotherm Res 91:1-21

Hansell AL, Horwell CJ, Oppenheimer C (2006) The health hazards of volcanoes and geothermal areas. Occup Env Med 63(2):149-156

Horwell CJ, Baxter PJ (2006) The respiratory health hazards of volcanic ash: a review for volcanic risk mitigation. Bull Volcanol 69:1-24

Institute of Electrical and Electronics Engineers (IEEE) Standard 80 (2000) IEEE guide for safety in AC substation grounding, IEEE Std 80-2000, New York, $200 \mathrm{p}$

Institute of Electrical and Electronics Engineers (IEEE) Standard 957 (2005) IEEE guide for cleaning insulators. IEEE Std 957-2005, New York, $77 \mathrm{p}$

SMEC International (1999) Rebuilding Rabaul. Paper prepared for the 1999 Engineering Excellence Awards. SMEC International Pty. Ltd

International Electrotechnical Commission (IEC) Standard 60815 (2008) Selection and dimensioning of high voltage insulators intended for use in polluted conditions, IEC/TS 60815, $108 \mathrm{p}$

Johnston DM (1997a) The impacts of recent falls of volcanic ash on public utilities in two communities in the United States of America. Institute of Geological \& Nuclear Sciences science report $97 / 5,21 \mathrm{p}$

Johnston DM (1997b) Physical and social impacts of past and future volcanic eruptions in New Zealand. Unpublished $\mathrm{PhD}$ thesis, Massey University, New Zealand

Johnston DM, Houghton BF, Neall VE, Ronan KR, Paton D (2000) Impacts of the 1945 and 1995-1996 Ruapehu eruptions, New Zealand: an example of increasing societal vulnerability. GSA Bull 112(5):720-726

Karady G (2007) Concept of energy transmission and distribution. In: Grigsby L (ed) Electric power generation, transmission and distribution. Taylor \& Francis, Boca Raton, Ch 8

Kim SH, Cherney EA, Hackam R (1990) The loss and recovery of hydrophobicity of RTV silicone rubber insulator coatings. IEEE Trans Power Deliv 5(3):1491-1500

Lannes W, Schneider H (1997) Pollution severity performance chart; key to just-in-time insulator maintenance. IEEE Trans Power Deliv 12(4):1493-1500

Lawrence RF (1988) The relation of electricity to society. Summary of an address on behalf of The Electrical Institute of Electrical and Electronics Engineers, IEEE Centennial Meeting. IEEE Power Engineering Review, Aug 1988

Mee M, Bodger P, Wardman J (2012) Volcanic ash contamination of high voltage insulators: revising insulator design to aid the electrostatic repulsion of volcanic ash. Proceedings of the Electricity Engineers Association Conference and Exhibition, 20-22 June 2012, Auckland, New Zealand

Meredith I (2007) Sharing experiences with applying coating to turbines. Hydro Rev Worldw 15(3):34,36-38,40-41

Miller TP, Chouet BA (eds) (1994) The 1989-1990 eruptions of Redoubt Volcano, Alaska. J Volcanol Geotherm Res 62:530

Nellis CA, Hendrix KW (1980) Progress report on the investigation of volcanic ash fallout from Mount St. Helens. Bonneville Power Administration, Laboratory Report ERJ-80-47, $44 \mathrm{p}$

Porter K, Kennedy R, Bachman R (2007) Creating fragility functions for performance based earthquake engineering. Earthq Spectra 23:471-489

Richards CN, Renowden JD (1997) Development of a remote insulator contamination monitoring system. IEEE Trans Power Deliv 12 (1):389-397

Rinaldi SM, Peerenboom JP, Kelly TK (2001) Identifying, understanding and analysing critical infrastructure independencies. IEEE Control Syst Mag 21:11-25

Rogers, E.J. (1982) Volcanic ash modified safety characteristics of the Schrag substation grounding grid. Bonneville Power Administration Laboratory Report ERJ-82-12, 12 p
Rose WI, Durant AJ (2009) Fine ash content of explosive eruptions. J Volcanol Geotherm Res 186(1-2):32-39

Rossetto T, Elnashai A (2003) Derivation of vulnerability functions for European-type RC structures based on observational data. Eng Struct 25:1241-1263

Sarkinen CF, Wiitala JT (1981) Investigation of volcanic ash in transmission facilities in the Pacific Northwest. IEEE Trans Power Appar Syst PAS-100:2278-2286

Siebert L, Simkin T (2002) Volcanoes of the world: an illustrated catalog of Holocene volcanoes and their eruptions. Smithsonian Institution, Global Volcanism Program Digital Information Series, GVP-3. http://www.volcano.si.edu/world/. Accessed 12 Dec 2011

Spence RJ, Kelman I, Baxter PJ, Zuccaro G, Petrazzuoli S (2005) Residential building and occupant vulnerability to tephra fall. Nat Hazards Earth Syst Sciences 5:477-494

Sundararajan R, Gorur RS (1996) Role of non-soluble contaminants on the flashover voltage of porcelain insulators. IEEE Trans Dielectrics Electrical Insulation 3(1):113-118. doi:10.1109/ 94.485522

Sword-Daniels, VL (2010) The impacts of volcanic ash fall on critical infrastructure systems. Unpublished Masters thesis, Department of Civil, Environmental and Geomagnetic Engineering, University College London, UK, $104 \mathrm{p}$

Sword-Daniels V, Wardman J, Stewart C, Wilson T, Johnston D, Rossetto T (2011) Infrastructure impacts, management and adaptations to eruptions at Volcán Tungurahua, Ecuador, 1999-2010. GNS Science Report 2011/24, 76 p

Transpower (1995) Report on volcanic ash contamination. Unpublished internal report, $15 \mathrm{p}$

Wardman J, Sword-Daniels V, Stewart C, Wilson T (2012a) Impact assessment of the May 2010 eruption of Pacaya volcano, Guatemala. GNS Science Report 2012/09, 99 p

Wardman J, Wilson T, Bodger P, Cole J, Johnston D (2012b) Investigating the electrical conductivity of volcanic ash and its effect on HV power systems. Phys Chem Earth. doi:10.1016/ j.pce.2011.09.003

Wightman A, Bodger P, (2011) Volcanic Ash Contamination of High Voltage Insulators. Proceedings from the Electrical Engineers Association Conference, Auckland, New Zealand, 23-24 June, 2011, 17 p

Wilson T, Daly M, Johnston D (2009) Review of impacts of volcanic ash on electricity distribution systems, broadcasting and communication networks. Auckland Engineering Lifelines Group (AELG) Technical Report No.051, $79 \mathrm{p}$

Wilson TM, Cole JW, Stewart C, Cronin SJ, Johnston DM (2011) Ash storm: impacts of wind remobilised volcanic ash on rural communities and agriculture following the 1991 Hudson eruption, southern Patagonia, Chile. Bull Volcanol 73(3):223-239

Wilson T, Stewart C, Sword-Daniels V, Leonard G, Johnston D, Cole J, Wardman J, Wilson G, Barnard S (2012) Volcanic ash impacts on critical infrastructure. Phys Chem Earth. doi:10.1016/ j.pce.2011.06.006

Wu D, Astrom U, Almgren B, Soderholm S (1998) Investigation into alternative solutions for HVDC station post insulators. Proceedings of the 1998 International Conference on Power System Technology, POWERCON '98, 1:512-515

Wu G, Cao H, Xu X, Xiao H, Li S, Xu O, Liu B, Wang O, Wang Z, Ma Y (2009) Design and application of inspection system in a self-governing mobile robot system for high voltage transmission line inspection. Proceedings of the 2009 Power and Energy Engineering Conference, APPEEC 2009, Asia-Pacific, pp 1-4

Yasuda M, Fujimura T (1976) A study and development of high water pressure hot-line insulator washing equipment for $500 \mathrm{kV}$ substation. IEEE Trans Power Appar Syst PAS-95(6):1919-1932 